San Jose State University

SJSU ScholarWorks

Mineta Transportation Institute Publications

$7-2021$

\title{
A Model for Integrating Rail Services with other Transportation Modalities: Identifying the Best Practices and the Gaps for California's Next State Rail Plan
}

\author{
Eric Peterson \\ Mineta Transportation Institute \\ Wenbin Wei \\ San Jose State University, wenbin.wei@sjsu.edu \\ Lydon George \\ San Jose State University
}

Follow this and additional works at: https://scholarworks.sjsu.edu/mti_publications

Part of the Infrastructure Commons, and the Transportation Commons

\section{Recommended Citation}

Eric Peterson, Wenbin Wei, and Lydon George. "A Model for Integrating Rail Services with other Transportation Modalities: Identifying the Best Practices and the Gaps for California's Next State Rail Plan" Mineta Transportation Institute Publications (2021). https://doi.org/10.31979/mti.2021.1949

This Report is brought to you for free and open access by SJSU ScholarWorks. It has been accepted for inclusion in Mineta Transportation Institute Publications by an authorized administrator of SJSU ScholarWorks. For more information, please contact scholarworks@sjsu.edu. 


\section{SJSU SAN SOSE STATIE}

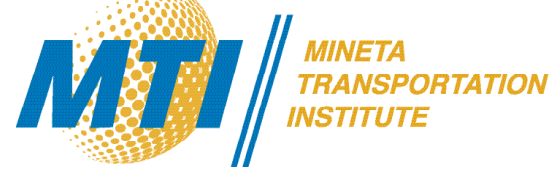

A Model for Integrating Rail Services with other Transportation Modalities: Identifying the best Practices and the Gaps for

California's Next State Rail Plan

Eric Peterson

Wenbin Wei

Lydon George

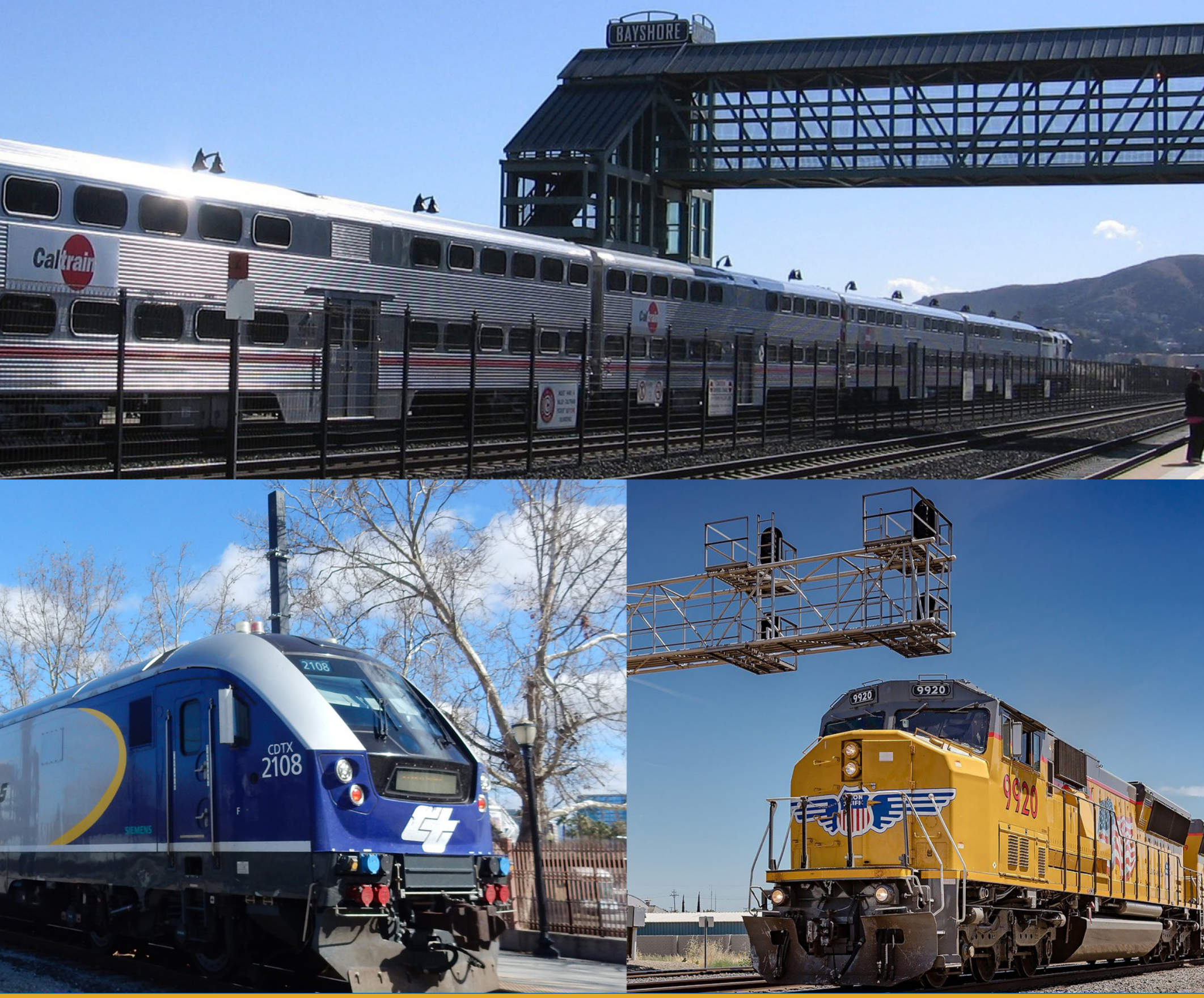




\section{Mineta Transportation Institute}

Founded in 1991, the Mineta Transportation Institute (MTI), an organized research and training unit in partnership with the Lucas College and Graduate School of Business at San José State University (SJSU), increases mobility for all by improving the safety, efficiency, accessibility, and convenience of our nation's transportation system. Through research, education, workforce development, and technology transfer, we help create a connected world. MTI leads the Mineta Consortium for Transportation Mobility (MCTM) funded by the U.S. Department of Transportation and the California State University Transportation Consortium (CSUTC) funded by the State of California through Senate Bill 1. MTI focuses on three primary responsibilities:

\section{Research}

MTI conducts multi-disciplinary research focused on surface transportation that contributes to effective decision making. Research areas include: active transportation; planning and policy; security and counterterrorism; sustainable transportation and land use; transit and passenger rail; transportation engineering; transportation finance; transportation technology; and workforce and labor. MTI research publications undergo expert peer review to ensure the quality of the research.

\section{Education and Workforce}

To ensure the efficient movement of people and products, we must prepare a new cohort of transportation professionals who are ready to lead a more diverse, inclusive, and equitable transportation industry. To help achieve this, MTI sponsors a suite of workforce development and education opportunities. The Institute supports educational programs offered by the Lucas Graduate School of Business: a
Master of Science in Transportation Management, plus graduate certificates that include High-Speed and Intercity Rail Management and Transportation Security Management. These flexible programs offer live online classes so that working transportation professionals can pursue an advanced degree regardless of their location.

\section{Information and Technology Transfer}

MTI utilizes a diverse array of dissemination methods and media to ensure research results reach those responsible for managing change. These methods include publication, seminars, workshops, websites, social media, webinars, and other technology transfer mechanisms. Additionally, MTI promotes the availability of completed research to professional organizations and works to integrate the research findings into the graduate education program. MTI's extensive collection of transportation-related publications is integrated into San José State University's world-class Martin Luther King, Jr. Library.

\section{Disclaimer}

The contents of this report reflect the views of the authors, who are responsible for the facts and accuracy of the information presented herein. This document is disseminated in the interest of information exchange. MTI's research is funded, partially or entirely, by grants from the California Department of Transportation, the California State University Office of the Chancellor, the U.S. Department of Homeland Security, and the U.S. Department of Transportation, who assume no liability for the contents or use thereof. This report does not constitute a standard specification, design standard, or regulation. 


\title{
A Model for Integrating Rail Services with other Transportation Modalities: Identifying the best Practices and the Gaps for California's Next State Rail Plan
}

\author{
Eric Peterson \\ Wenbin Wei \\ Lydon George
}

July 2021 


\section{TECHNICAL REPORT DOCUMENTATION PAGE}

\begin{tabular}{|c|c|c|c|}
\hline $\begin{array}{l}\text { 1. Report No. } \\
21-21\end{array}$ & 2. Government Accession No. & \multicolumn{2}{|c|}{ 3. Recipient's Catalog No. } \\
\hline \multirow{2}{*}{\multicolumn{2}{|c|}{$\begin{array}{l}\text { 4. Title and Subtitle } \\
\text { A Model for Integrating Rail Services with oth-er Transportation Modalities: } \\
\text { Identifying the best Practices and the Gaps for California's Next State Rail Plan }\end{array}$}} & \multicolumn{2}{|l|}{ 5. Report Date } \\
\hline & & \multicolumn{2}{|c|}{ 6. Performing Organization Code } \\
\hline \multicolumn{2}{|l|}{$\begin{array}{l}\text { 7. Authors } \\
\text { Eric Peterson: 0000-0002-0125-4024 } \\
\text { Wenbin Wei: 0000-0002-2044-9345 } \\
\text { Lydon George: 0000-0001-5055-6224 }\end{array}$} & \multicolumn{2}{|c|}{$\begin{array}{l}\text { 8. Performing Organization Report } \\
\text { CA-MTI-1949 }\end{array}$} \\
\hline \multirow{2}{*}{\multicolumn{2}{|c|}{$\begin{array}{l}\text { 9. Performing Organization Name and Address } \\
\text { Mineta Transportation Institute } \\
\text { College of Business } \\
\text { San José State University } \\
\text { San José, CA 95192-0219 }\end{array}$}} & \multicolumn{2}{|c|}{ 10. Work Unit No. } \\
\hline & & \multicolumn{2}{|c|}{$\begin{array}{l}\text { 11. Contract or Grant No. } \\
65 \mathrm{~A} 0660\end{array}$} \\
\hline \multirow{2}{*}{\multicolumn{2}{|c|}{$\begin{array}{l}\text { 12. Sponsoring Agency Name and Address } \\
\text { California Department of Transportation } \\
1120 \text { N Street } \\
\text { Sacramento, CA } 95814\end{array}$}} & \multicolumn{2}{|c|}{ 13. Type of Report and Period Covered } \\
\hline & & \multicolumn{2}{|c|}{ 14. Sponsoring Agency Code } \\
\hline \multicolumn{4}{|l|}{ 15. Supplemental Notes } \\
\hline \multicolumn{4}{|c|}{$\begin{array}{l}\text { 16. Abstract } \\
\text { The California State Rail Plan (CSRP) is among the best rail plan documents published by any jurisdiction in the United } \\
\text { States to date. As such, the CSRP is used in this paper as the basis of comparison to other state rail service plans. These } \\
\text { plans will have been submitted to the Federal Railroad Administration (FRA) on record as of June 2020-as required un- } \\
\text { der Section } 303 \text { of the Passenger Rail Investment and Improvement Act (PRIIA) of 2008. The purpose of this paper is to } \\
\text { identify the best practices and gaps that may inform California and other states in their future rail service plan develop- } \\
\text { ment. } \\
\text { This paper is grounded in the realization that, while the general outline of FRA requirements is uniform for all } \\
\text { states, the actual content and inclusion of these requirements in the myriad state plans varies greatly. For example, Califor- } \\
\text { nia was granted an exception to help update FRA Rail Plan Guidance for its } 2018 \text { Rail Plan, other states have complained } \\
\text { that FRA guidance and requirements on rail service planning have put state rail agencies in the position of constantly writ- } \\
\text { ing plans with little or no time to implement them. } \\
\text { Throughout this research, the authors identify all the elements of FRA guidelines as reflected in the CSRP and rail } \\
\text { plans of other states. This report also identifies the best features and planning strategies that may inform and improve the } \\
\text { state rail planning process going forward, steps that will positively contribute to the public benefit of enhanced rail systems. }\end{array}$} \\
\hline $\begin{array}{l}\text { 17. Key Words } \\
\text { Passenger rail, freight rail, inter- } \\
\text { modal, rail planning, transportation } \\
\text { planning }\end{array}$ & \multicolumn{3}{|c|}{$\begin{array}{l}\text { 18. Distribution Statement } \\
\text { No restrictions. This document is available to the public through The National } \\
\text { Technical Information Service, Springfield, VA } 22161 .\end{array}$} \\
\hline $\begin{array}{l}\text { 19. Security Classif. (of this report) } \\
\text { Unclassified }\end{array}$ & $\begin{array}{l}\text { 20. Security Classif. (of this page) } \\
\text { Unclassified }\end{array}$ & $\begin{array}{l}\text { 21. No. of Pages } \\
35\end{array}$ & 22. Price \\
\hline
\end{tabular}

Form DOT F 1700.7 (8-72) 
Copyright (C) 2021

\section{by Mineta Transportation Institute}

All rights reserved.

DOI: $10.31979 / \mathrm{mti} .2021 .1949$

Mineta Transportation Institute College of Business

San José State University

San José, CA 95192-0219

Tel: (408) 924-7560

Fax: (408) 924-7565

Email: mineta-institute@sjsu.edu

transweb.sjsu.edu/research/1949 


\section{ACKNOWLEDGMENTS}

The authors thank Editing Press for their editorial services, as well as Mineta Transportation Institute's Deputy Executive Director Hilary Nixon, Ph.D., and Caltrans Transportation Planners Kayo Lao, Stuart Mori, Joshua Pulverman, Tyler Monson, Chad Riding, Shannon Simonds, Andrew Cook, Mark Sidorenko, and Hayley Rundle.

Cover Image credit: Lydon George and Pixabay.com. 


\section{CONTENTS}

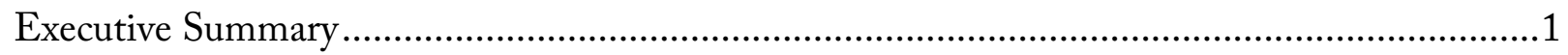

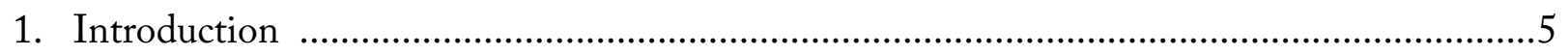

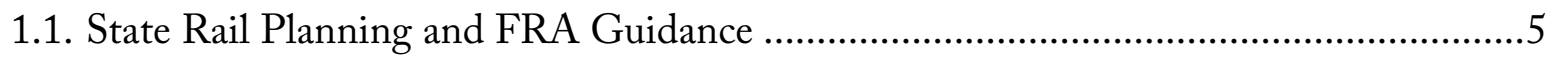

1.2. The Purpose of This Research ...............................................................................

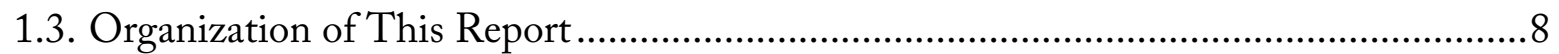

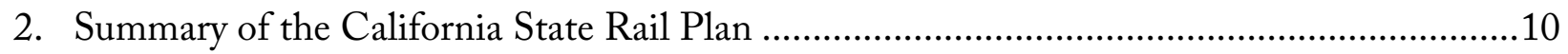

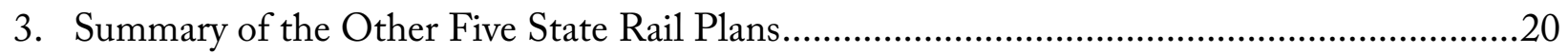

3.1. The Colorado State Freight and Passenger Rail Plan: March 2012 (The latest plan

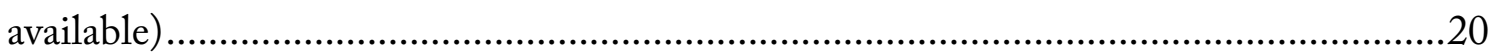

3.2. The Michigan State Rail Plan_Final Report: September 2011 ...................................23

3.3. North Carolina Rail Division Comprehensive State Rail Plan: August 2015 ................26

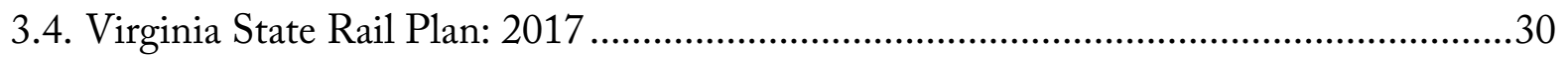

3.5. Washington State Rail Plan: 2019-2040 .................................................................... 34

4. Comparison of California State Rail Plan with Others .......................................................40

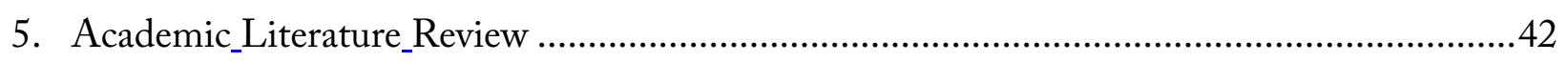

5.1. Connectivity of Rail and Other State Infrastructure-Freight......................................42

5.2. Connecting Rail to Consumers and End Users..............................................................4

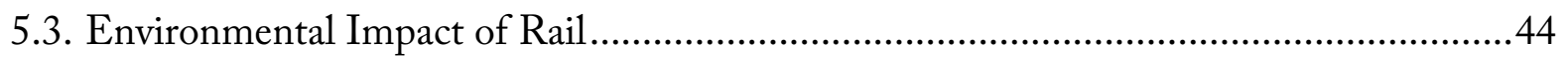

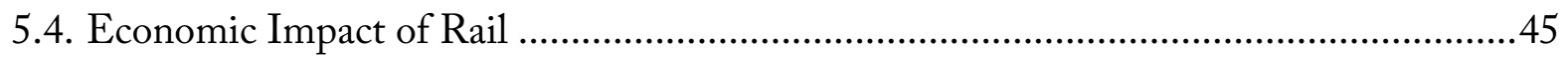

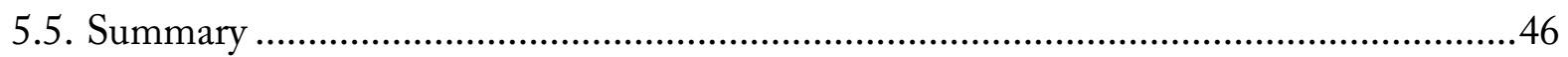

6. Recommendations for the Next California State Rail Plan..................................................48

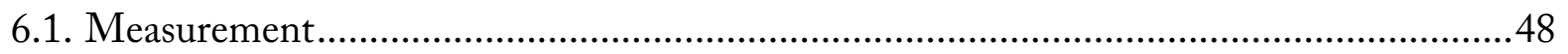

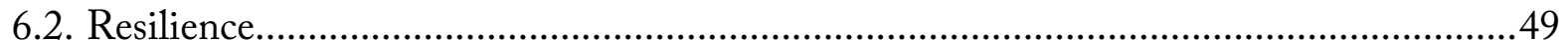

6.3. Parallels to the Interstate Highway System .................................................................. 49

6.4. Innovative Rail Funding and Financing ...................................................................50

6.5. Decision-Making Frameworks and Tools for Future System Performance ...................51

6.6. Establish State and Regional Rail Advisory Bodies.........................................................51

6.7. Periodic Review of Rail Plan Implementation ............................................................52

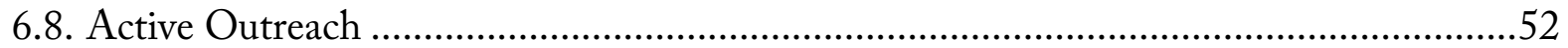

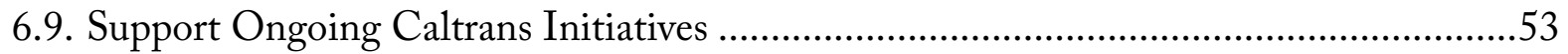

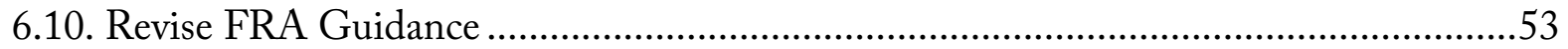

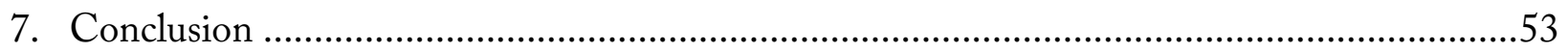

Appendix A: Matrix of State Rail Plans According to the FRA_Requirements..........................56

Abbreviations and Acronyms .................................................................................................6 


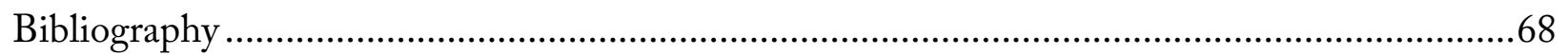

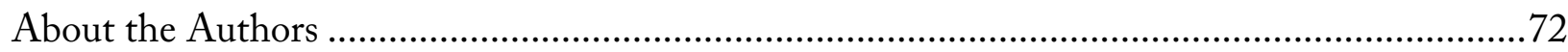




\section{Executive Summary}

While the general outline of the Federal Railroad Administration's (FRA) guidance is uniform for all states, the actual content and breadth of coverage of state rail service plans vary greatly. For example, while California was granted an exception to help update FRA rail plan guidance for its 2018 California State Rail Plan (CSRP), other states have expressed concern that they devote more time to planning and therefore lack the time and resources to actually implement those plans. Reviewing state rail plans for all 50 states, as well as assessing academic considerations of statelevel rail planning, the authors sought to understand the environment of state-level rail planning. The goal of this report is to identify the best practices and gaps that may inform California and other states as they develop their future rail service plans.

Through this research, the authors have:

- identified all the elements of the FRA guidance as they are reflected in the 2018 CSRP and other states; and

- identified the best features and planning strategies that may inform and improve the state rail planning process going forward.

The research involved four steps:

- reviewing and preparing text outlining the elements of the FRA's 2013 state rail plan guidance;

- identifying and reviewing other sources of rail or transit plans;

- summarizing, comparing, and evaluating innovative practices of these plans; and

- preparing commentary and analysis identifying improvements that California and other states could make in preparing and submitting future rail service plans.

Based on the analysis of state rail plans, as well as academic discussion of state rail planning, the following recommendations are offered:

(1) Measurement: As noted in this report, both the FRA and many states take a light touch to setting measurable goals for the performance of their rail infrastructure, with exception to on-time performance of passenger and freight rail service. This exception has been the subject of legislative, regulatory, and judicial deliberations. In both the legislative mandate for state rail planning and the regulatory guidance for those planning efforts, there are major gaps in performance measurability that significantly limit the value and impact of these planning efforts.

For example, there are no metrics that track the progress of any states' planning efforts. No systems are in place to track the aspirational goals and expressions between plan updates, nor are there 
metrics that set goals to be addressed in future plans. How are decision-makers to know what success is or looks like?

The bottom line for the CSRP — and for that matter all state rail plans - is that aspiration is not a plan. Demonstrating achievement and measuring progress toward future goals will instill credibility and confidence in state rail planning, enabling intercity passenger rail, high-speed passenger rail, and all other forms of public transportation to be able to justify the necessary investment of resources. These measures of success will position the state to further pursue federal funding through performance-based grants and providing environmentally acceptable mobility options for passenger and freight movement in the $21^{\text {st }}$ century.

(2) Resilience: Another area not addressed in the CSRP or in other state rail plans are the topics of infrastructure resilience, asset management, and state of good repair. Recent natural disasters and the various emerging and ongoing pandemics suggest that the federal government, states, and service providers need to be more proactive in improving resiliency of rail infrastructure. Proactive resiliency initiatives would ensure and demonstrate high levels of good repair asset management and resilience to natural disasters. Future state rail plans and state transportation plans must evaluate and provide specific guidance to ensure funding and implementation of resilience in rail infrastructure.

(3) Parallels to the Interstate Highway System: Advocates for improved inter-city and high-speed passenger rail, as well as improvements to the nationwide freight rail system, rarely mention the strategic importance of rail networks to the nation's defense. North Carolina's state rail plan, however, discussed at great length "Stracnet"-the 36,000 miles of rail lines throughout the United States that helps deliver defense materials and personnel to military and other key strategic facilities.

The role of the states and the interests of the federal government still frame the debate over providing federal funding to support intra and interstate rail passenger service. However, with the vast array of economic, environmental, and other national interests at play, there remain many policy gaps and opportunities that share similarities to those that framed the policies leading to the creation of the Interstate Highway System, which President Eisenhower, in his 1954 state of the union message, justified as a national defense program. These policies and their potential application to rail investment should be considered, as the states and the federal government address the renaissance of freight and passenger rail in the United States. ${ }^{1}$

(4) Innovative Rail Funding and Financing: States such as California, Colorado, and Virginia are using a wide range of strategies to fund and finance the development and improvement of rail service. Assessment of benefits/costs and returns on investments for rail related expenditures is

${ }^{1}$ US Senate "Federal-Aid Highway Act". 
critical in determining the maintenance of current levels of service and development of new capacities. In order for stakeholders ranging from the general public to policy makers, to understand the ramifications of various funding and financing scenarios, more specific evaluation and analysis needs to be included in future state rail planning efforts.

(5) Decision-Making Frameworks and Tools for Future System Performance: The decisionmaking challenges facing state transportation agencies are becoming increasingly complex, as they work to develop strategies to ensure right-sized, high performing, and sustainable transportation systems that also support robust economic growth.

Future transportation systems will be judged on their ability to balance the need to deliver services efficiently, equitably, and sustainably while supporting economic growth. Yet, the ability of any organization - particularly state transportation agencies - to predict and plan for future rail needs over the next several decades is confounding.

Decision-making efforts will require quantification and forecasting based on industry metrics and methodologies that are yet to be developed. These include performance measures related to population, economic factors, trip making, asset condition/performance, life cycle benefits/costs, equity, and safety. Other issues are more difficult to predict or quantify, including future technology, energy, sustainability, resiliency, workforce capacity, and governance and institutional frameworks.

To ensure that future rail planning efforts assist state departments of transportation and other transportation agencies with strategic decision-making, plans must address future trends and changing goals, and make recommendations regarding:

- new definitions and standards for system performance;

- frameworks for decisions needed to optimize performance; and

- a catalog of information and tools that can be used within those frameworks to achieve high performance.

(6) Establish State and Regional Rail Advisory Bodies: According to the FRA's state rail planning guidance of 2013, the Passenger Rail Investment and Improvement Act of 2008 (PRIIA) requires states to establish or designate-by state law or the direction of the Governor-a "State Rail Transportation Authority" (SRTA). PRIIA also requires states to establish or designate a "State Rail Plan Approval Authority" (SRPAA). The SRPAA would be responsible for reviewing and approving a state's rail plan.

While many states have taken steps to establish SRTAs and SRPAAs, several have not. For those states that have established such bodies, every effort must be made to ensure that the work of these authorities is fully transparent, providing regular reports to legislative oversight committees and to the general public. Additionally, every effort must be made to obtain input from the broader spectrum of stakeholders as California, Colorado, Virginia, and Washington state have done. 
(7) Periodic Review of Rail Plan Implementation: FRA guidance requires that states update their rail plans every four years. In reviewing the respective state plans for this study, it was observed that several states' rail plans are over ten years old, while other states are more current. California, for example, is currently in the process of updating its plan with an eye toward publishing a revised plan within the next year.

While preparing this study, a reoccurring comment made by state agencies was that they are so busy preparing plans that they don't have time to implement them. The bottom-line objective of planning is to develop and implement strategies that can be easily reviewed, successfully implemented, and produce measurable results. North Carolina and Virginia seem to be leaders in this regard, with many states making considerable efforts to improve rail strategy implementation and performance on an ongoing basis.

(8) Active Outreach: Public support is crucial to the advancement of rail initiatives in California, whether it is the planning and construction of major rail infrastructure, or the implementation of new rail services and features.

California and, for that matter, many other states should increase efforts to actively create dialogue with the general public and to communicate future rail plans in a clear and effective way. This improved transparency would help educate a car-reliant public on the benefits of rail transit, enhancing social and political support of rail enhancement. These efforts would also improve communication methods between transit agencies and stakeholders across the state, optimizing coordination and efficiency in implementation of rail related initiatives.

(9) Support Ongoing Initiatives by Caltrans: The CSRP initiatives and strategies reviewed in this paper were published in 2018, providing a foundation upon which new rail plans will be developed. In the Spring of 2020, Caltrans released "Analysis of Proposed Cal-ITP Initiatives: A Feasibility Study." This study is intended to establish the foundation for the state's 2022 State Rail Plan. A primary focus of the Cal-ITP Initiative details a strategic vision for a coordinated, integrated state rail network.

The concepts presented in the Cal-ITP study are consistent with many of the recommendations of this paper and with Caltrans' ongoing integrated mobility initiatives, including trip planning, payment, and equity. It is recommended that new concepts and future rail plans be evaluated to address all opportunities for enhancement, including the creation, involvement, and periodic review of rail advisory bodies to support ongoing multi-modal initiatives by Caltrans.

(10) Revise FRA Guidance: FRA state rail plan guidance, last updated in 2013, should be updated to encourage all states to do more than "check the boxes", with the ultimate goal of establishing a "national rail policy and plan" as a means to integrate all state rail plans. The FRA may also follow the lead of California to implement less proscriptive reviews and acceptance of the state rail plans. 


\section{Introduction}

\subsection{State Rail Planning and FRA Guidance}

Based on the elements of the FRA state rail planning guidance for state rail plan preparation established by the Passenger Rail Investment and Improvement Act of 2008 (PRIIA), ${ }^{2}$ the FRA requests that states prepare and update their state rail plans at least every four to five years. The FRA "State Rail Plan Guidance" provides a template for the content of state plans and outlines the expectations and intentions of the FRA. Under Section 303 of the PRIIA, each state must develop their own State Rail Plans according to specific requirements. The submission to and acceptance of a state's rail plan by the FRA is a requirement for a state to apply for the capital grants available for high-speed rail projects (Section 501), intercity passenger rail (Section 301), and high priority congestion corridors (Sections 302). FRA combined these three PRIIA programs into a single coordinated program called the High-Speed Intercity Passenger Rail Program (HSIPRP). Each state is required to coordinate their state rail plan with their respective statewide/nonmetropolitan and/or metropolitan transportation planning processes-which are administered by the Federal Highway Administration (FHWA) and the Federal Transit Administration (FTA). The HSIPRP provides funding for each state to complete the state rail plan. Additional funding support may also be available from the FHWA and FTA.

The FRA guidance charges state and local officials and other stakeholders with four major responsibilities in preparing their state rail plans specified by PRIIA. They must:

- establish a state authority to develop and approve the rail plan;

- coordinate with other statewide/nonmetropolitan and/or metropolitan transportation planning activities;

- involve the public and other stakeholders in the planning process; and,

- coordinate with neighboring jurisdictions.

The FRA guidance also summarized the four major roles that the FRA plays in the state rail planning process. These roles are:

- establishing minimum content requirements, recommended format, and submittal guidelines;

- providing funding to each state for developing the rail plans;

${ }^{2}$ USDOT, “The Passenger Rail Investment and Improvement Act of 2008.” 
- coordinating state rail plans with multi-state and national rail planning activities; and,

- providing technical assistance.

Most importantly, the FRA guidance lists the standard format for the state rail plans and data requirements. Its major components include:

Executive Summary

Chapter 1: The Role of Rail in Statewide Transportation (Overview)

Chapter 2: The State's Existing System

2.1 The State's Existing Rail System: Description and Inventory

2.2 The State's Existing Rail System: Trends and Forecasts

2.3 The State's Existing Rail System: Rail Service Needs and Opportunities

Chapter 3: Proposed Passenger Rail Improvements and Investments

Chapter 4: Proposed Freight Rail Improvements and Investments

Chapter 5: The State's Rail Service and Investment Program

Chapter 6: Coordination and Review

Technical Appendix: Documentation of Technical Assumptions and Procedural Steps

The FRA guidance also lists the major steps that should be taken in preparing and revising the State Rail Plans at least every four (originally five) years. This includes coordination with FRA, state approval, submission to FRA, FRA review, and state rail plan updates. ${ }^{3}$ At the end of the FRA guidance, three major appendices are included:

- Additional data requirements with corresponding elements in standardized format;

- State rail plan content requirements; and,

- PRIIA capital programs.

These appendices are intended to encourage the states to provide more detail and present their plans in a more uniform fashion.

\footnotetext{
${ }^{3}$ Over the course of this research project, some states, including Colorado and California, submitted updates to the plans that were on file at the outset of this project. The structure of those plans has not changed and is still in accordance with the FRA's 2013 guidance. Detailed analysis of the plans in this report make use of the plans that were on file when the research started.
} 


\subsection{The Purpose of this Research}

In 2009, the American Association of State Highway and Transportation Officials (AASHTO) published, "State Rail Planning Best Practices: A Detailed Review of All Existing Statewide Rail Plans." Subsequently, AASHTO surveyed those states that responded to the PRIIA guidance and published a second volume of "Best Practices" in 2016. Through this review, and through interaction with an advisory council of state rail planners organized by AASHTO, the two publications identified best practices across several different categories. These categories included visioning and goal setting, system inventory and use, and evaluation approaches.

The authors of the two AASHTO research projects made several presentations of draft instructional materials at AASHTO's annual and semi-annual SCORT (Standing Committee on Rail Transportation) meetings. These were presented to a broad group of states, railroads, and other stakeholders. The presentations distilled the findings of the best practices review into a guidebook that also met federal standards and guidelines for rail plans. Before publication and distribution to the states, the authors worked closely with AASHTO and several state rail officials. Their work consisted of careful review and customization of the guidebook to provide timely and flexible guidance to states. The FRA also reviewed the guidebook and endorsed its use by AASHTO to help states advance rail planning efforts.

With more than ten years of rail planning experience since the passage of PRIIA, states are shifting from attempting to understand the purpose of creating state rail plans to refining their plans in order to make those plans more useful. State rail plans, in their future iterations, will seek to prioritize rail improvement projects as well as improve the efficient operation of rail infrastructure in conjunction with other transportation modes in their states and regions. Based on the FRA guidance, this research project's first task is to review the individual state rail plans on record with the FRA and identify where in each plan the requested elements are found. This review is reflected in Appendix A: FRA State Rail Plan Requirements Matrix. In this appendix, each state is listed alphabetically along the left-hand side and the requested plan components are arrayed across the top of the matrix. Under each component, the location of the requested information is noted for each state's plan.

As noted earlier, there are eight components that the FRA requested each state to address in their plans. Virtually every state, with the exceptions of Nebraska and South Dakota, addressed all eight components. Some states were very thorough in addressing all the components. Some states addressed all the required components and provided additional information in their plans. These components include:

- connectivity of rail infrastructure to other elements of the state's transportation infrastructure;

- connectivity of rail infrastructure with consumers and end users; 
- environmental impact of their rail infrastructure; and

- infrastructural impact on economic development.

Some plans did not provide an executive summary but offered an overview which appears to be a combination of an executive summary and a description of the role of rail in the state. The FRA requested for this to be presented in Chapter 1 of the respective plans. Most states' plans have technical appendices and numerous tables and figures.

In the case of Nebraska, their plan did not display recognition of the FRA guidance in any manner, focusing strictly on discussions of moving agriculture products to market. In the case of South Dakota, all FRA-desired components were addressed except intercity passenger rail. One can only presume that the South Dakota Department of Transportation did not address intercity passenger rail because the state has no intercity passenger rail service - and has no plans for developing any such service. States that stood out to the FRA as going well beyond the basic requirements of the State Rail Plan Guidance were California, Colorado, Michigan, North Carolina, Virginia, and Washington State. ${ }^{4}$

FRA staff noted that, while every state's plan offers room for improvement in the next planning cycle, these six states were more visionary. They also reflected a greater awareness that their respective rail infrastructures were part of something bigger than just the railroad tracks that ran through their states.

The significance of Appendix A is that it provides an inventory of each state's plan and enables the reader to obtain a visual awareness of the complexity and content of each plan. In later chapters of this paper, a closer examination and comparison of the details of each plan will be presented with an eye toward identifying the gaps and best practices that may help California rail planners (and those of other states) improve their plans in the next planning cycle.

\subsection{Organization of this Report}

In Chapter 1 of this report, we provide a brief review of state rail planning and FRA guidance, and state clearly the purpose and objectives of this research. A matrix of each state's rail plan according to the FRA requirements is provided in Appendix A.

Chapter 2 presents a review, critique and summary of the California State Rail Plan (CSRP) in the context of the FRA guidance.

In Chapter 3, we provide a review of the rail plan of other states, especially five states: Colorado, Michigan, North Carolina, Virginia, and Washington. That were specifically cited by FRA staff for their innovative and forward-looking rail planning presentations.

\footnotetext{
${ }^{4}$ Will Dyer and Lyle Leitelt, Planning Staff, Personal/Phone Interview (Washington, District of Columbia, 2020).
} 
In Chapter 4, we compare the CSRP with those of other states, based on the review of the CSRP in Chapter 2 and other states' rail plans in Chapter 3, using the exact chapter structure of the 2013 FRA Rail Planning Guidance.

In Chapter 5, we identify and review academic sources of state-level rail or transit planning and summarize, compare, and evaluate innovative practices in comparison to existing state rail planning initiatives.

In Chapter 6, we make recommendations on how the next California State Rail Plan can be improved based on the reviews and comparisons in the previous chapters.

In Chapter 7, we conclude this report with a summary of our research. 


\section{Summary of the California State Rail Plan}

This chapter provides information regarding the key features of the CSRP published in 2018. Also addressed in this chapter are identified gaps and suggested improvements that Caltrans may wish to address in its next planning cycle.

As noted in executive summary of this paper, California is recognized as the leading example of robust rail planning in the nation. Its 2018 state rail plan addresses the broad range of issues and aspects set forth in both PRIIA and the subsequently released State Rail Planning Guidance issued by the FRA in 2013.

The CSRP provides a comprehensive overview of its contents, strategies and process for the plan's development, a fulsome explanation of its development and use, and a robust description of the interconnection and vital role both freight rail and passenger rail play in the state's transportation system.

In its seven chapters, the CSRP thoroughly examines each of the areas requested in the FRA guidance, including the role of rail in the statewide transportation system, a comprehensive description of the state's existing rail system, a vision of where California would like to see its rail system within the context of the state's transportation plan-including specific goals, a comprehensive description of both an inventory of proposed passenger rail improvements and investments and freight rail investments, and a detailed description of the outreach strategies used in the development of the 2018 CSRP.

Chapter 1 of the CSRP provides an overview of the plan and series of presentations and discussions, including:

A description of the state's multimodal transportation system including current trends and future opportunities, encompassing the following elements:

The role of rail in the state's transportation system including discussions regarding mobility, economic development and geographic changes, passenger rail demand and growth trends, freight demand and growth trends, land use and quality of life, environment, safety, and the interface of the state's rail system with tribal communities throughout the state.

- A discussion on the policies and programs that affect the state's rail system including federal and state policy trends, program coordination, and regional corridor and private-sector plans.

- A discussion of governance and funding including federal, state and local laws and powers for planning operating. 
- A description of passenger rail service delivery agencies, coordination among service providers, rail initiatives and plans, and the state's section 22102 compliance requirements. ${ }^{5}$

The conclusion of Chapter 1 projects that in order for the state's rail system to keep pace with anticipated population growth, the state's economic goals, and anticipated climate challenges, the state will need to develop its multimodal transportation system, including all aspects of its rail systems, to promote ever-greater efficiency in investment, economic output, energy use, and user capacity. To that end, the conclusion urges that there must be a redirection of legacy planning and investment solutions, new ways of strategizing investments, and adapting and leveraging the latest technological solutions. ${ }^{6}$

Chapter 2 presents an inventory of the existing passenger and freight rail system, abandoned rail lines, intermodal facilities and the safety and security measures in force throughout these systems. This chapter also discusses the constraint—natural and man-made-on the capabilities of these systems. The chapter concludes by observing that California's passenger rail system offers a great alternative to driving for residents, employees, visitors and businesses alike, with easy access to and transferability between intercity rail, commuter rail, urban rail and other connecting services like Amtrak Thruway buses. ${ }^{7}$

Picking up on the detail of Chapter 2, Chapter 3 presents a vision for the state's rail system that includes a description of how the rail plan fits within the context of the CTP 2040 including the state's Rail Plan Vision:

CTP 2040 Vision: Sustainability California's transportation system is safe, sustainable, universally accessible, and globally competitive. It provides reliable and efficient mobility for people, goods, and services, while meeting the State's greenhouse gas emission reduction goals and preserving the unique character of California's communities. ${ }^{8}$

The vision statement is supported by six goals that include:

1. Improve multimodal mobility and accessibility for all people.

2. Preserve the multimodal transportation system.

3. Support a vibrant economy.

4. Improve public safety and security.

\footnotetext{
${ }^{5}$ CA DOT "CA State Rail Plan" 1-50.

${ }^{6} \mathrm{CA}$ DOT "CA State Rail Plan" 50.

${ }^{7}$ CA DOT "CA State Rail Plan" 53-94.

${ }^{8}$ CA DOT “CA State Rail Plan” 99.
} 
5. Foster livable and healthy communities and promote social equality.

6. Practice environmental stewardship. ${ }^{9}$

Each of these goals is supported by a range of policy objectives that are intended to provide benefits to California residents and businesses while minimizing adverse impacts.

The vision and goals outlined in this chapter are integral to the state's rail service and investment program outlined in Chapter 6 of the CSRP, which measures the goals and objectives outlined here according to the following criterion:

- access and mobility — measured through forecasted changes in travel times; passenger rail ridership and revenue;

- environmental stewardship - measured through projected changes in GHG and criteria air pollutant emissions; consideration of actions taken to address rail-related noise; the extent to which projects and programs can support state climate change policies; and the extent to which sea level rise and extreme weather may affect rail corridors and investment needs;

- livable and healthy communities - measured by evaluating impacts on grade crossings, quiet zones, and other neighborhoods near rail lines, yards, and passenger stations and the extent to which expanded passenger rail service integrates with local transportation options;

- safety and security - effects are considered through summarizing research results regarding the demonstrated safety benefits of passenger and freight rail travel versus highway travel; and through including and prioritizing programs that directly fund rail safety improvements; and

- economic benefits - the potential job creation and economic growth effects gained as a result of recently completed economic and benefit-cost analyses, which are used to characterize enhanced real estate values near passenger rail stations. ${ }^{10}$

Chapter 3 concludes by observing that, even though the state's diversity is one of its strongest assets, it also "poses great challenges to safeguarding against climate impacts and preparing for future vulnerabilities."11

The conclusion recommends that the state maintain a robust, multimodal system and a state rail plan that can help by guiding rail planning and corresponding investments to a wide range of goals like reducing GHG emissions. Additionally, the conclusion suggests that "the 2040 Vision and planning framework details how a pulsed system incorporates integrated and complementary services, and can be sustainably executed through a phased investment strategy."

\footnotetext{
${ }^{9}$ CA DOT "CA State Rail Plan" 100.

${ }^{10}$ CA DOT "CA State Rail Plan" 117.

${ }^{11}$ CA DOT "CA State Rail Plan” 118.
} 
Chapters 4, 5, and 6 are, from a planning and investment perspective, the most important elements of the CSRP. Chapter 4 addresses proposed passenger improvements and investments for the California rail system. Chapter 5 addresses freight rail investment strategies, and Chapter 6 lays out the state's rail service and investment program.

Chapter 4 provides more detail on the application of the 2040 Vision as it relates to proposed passenger rail improvements and investments. Specifically, the chapter focusses on the pulsed scheduling concept as being central to the state's investment and connectivity strategies. ${ }^{12}$

The CSRP defines pulse scheduling as a mechanism that:

represents uniform train service patterns that repeat throughout the day on regular, recurring time intervals. This timetable-based planning approach allows for timed transfers between services at hub stations where a transfer is required to complete a trip across the state, or to a location served by local transit. The benefit to users of pulse scheduling is that a repeating timetable allows for easy trip planning and seamless travel by ensuring that connections between trains can be made throughout the day, with minimal transfer times.

According to the CSRP, pulse scheduling will provide significant cost savings for rail service operators, increase rail capacity, and improved connectivity for passenger rail customers.

Chapter 4 presents connectivity goals that support statewide service goals based on a "phasing" strategy. In the terms of the CSRP, phasing is a strategy intended to build capacity in three stages: short- term (2022); mid-term (2027); and, long-term (2040).

Within each time frame, the plan addresses both state and regional goals for nine areas including:

- Central Valley and Sierra Nevada;

- North San Francisco Bay Area and the North Coast;

- South San Francisco Bay Area;

- Central Coast;

- Las Vegas HSR;

- LOSSAN North;

- Los Angeles Urban Mobility Corridor; Inland Empire; and,

- LOSSAN South. ${ }^{13}$

${ }^{12}$ CA DOT “CA State Rail Plan” 121.

${ }^{13}$ CA DOT “CA State Rail Plan” 124-154. 
As the CSRP notes, these regions were defined through a network planning effort as a framework for understanding, discussing and organizing future services.

The geographic service regions described in this chapter were refined from a framework for understanding, discussing, and organizing future services in logical statewide rail travel sheds (areas around rail lines) that justified markets and ridership. ${ }^{14}$

The service goals and proposed improvements, as well as the planning, analysis and project development tasks identified in each time frame for each of the nine regions is impressive. Time will tell whether and how both the statewide goals and the respective regional goals and tasks will be achieved.

Because virtually all of California's rail system operates on a network of privately owned railroads, close cooperation, coordination, and incentives are necessary to ensure that the goals of Chapter 4 can be addressed and achieved. Consequently, Chapter 5 of the CSRP, "Freight Rail Investment Strategy," is critical to the success of this plan and future plans well beyond the timelines of Vision $2040 .{ }^{15}$

The CSRP declares that rail effectively provides highway congestion relief, facilitates the movement of people and goods, and while simultaneously improves and complements parallel trade corridors. $^{16}$

Recognizing the need for cooperation and collaboration between the public and private sectors in order to provide a functional rail system in the state, the CSRP notes the necessity of public/private interaction in order to support and enhance the entire statewide, multimodal transportation system. As such, Chapter 5 is organized on the basis of a corridor-based planning and investment strategy that addresses the gives deference to California's freight rail system in order to promote the long-term utility and viability of the current shared use rail system while acknowledging that a separate rail and freight systems are not likely for decades to come. Rather than identifying a comprehensive list of projects, the chapter describes categories of investments that will advance the state's vision for a rail network, depicting how they can impact California's economy, environment, and communities, and identifying opportunities where investments will be mutually beneficial for both passenger travel and goods movement. This chapter also articulates the state's strategy for improving the rail network in the context of transportation objectives defined in the CTP 2040 and the Governor's Sustainable Freight Action Plan, while laying the foundation for the next update of the California Freight Mobility Plan. ${ }^{17}$

This chapter takes a corridor-based approached to freight rail planning intended to identify projects that will intensify the use of existing infrastructure, and improve parallel and complementary

${ }^{14}$ CA DOT "CA State Rail Plan" 125.

${ }^{15}$ CA DOT "CA State Rail Plan” 167-182.

${ }^{16}$ CA DOT "CA State Rail Plan" 167.

${ }^{17}$ CA DOT “CA State Rail Plan” 168. 
routes or projects especially in corridors with Trans America freight routes that connect sea ports along the east and west coasts as well as the Gulf of Mexico.

Earlier state rail plans identified funding priorities based on the amount of gross tonnage being carried on the existing freight rail system. An important element of corridor-based planning is adopting criteria for defining, selecting, and prioritizing corridors. Volumes of tonnage is one measure. Others include:

- critical connections to transcontinental routes;

- railroad classification;

- location, with respect to land and sea ports; and

- available alternatives for port traffic. ${ }^{18}$

The CSRP advocates that defining freight corridors allows transportation agencies at the local, regional, and State levels to better collaborate to identify multimodal approaches to solving problems and prioritizing funding. This collaboration, according to the CSRP, can promote synergies that have the potential of producing a wide range of benefits that might not otherwise be realized. These benefits include "transportation decisions and non-transportation decisions such as land use planning, zoning, and environmental regulations that could help decision makers invest more strategically for the greatest benefit and efficiency."

The plan notes that freight rail corridors are categorized as:

- "Primary Trade Corridors" that require investment in dedicated freight capacity;

- "Shared Corridors" in which the state is making investments to expand the passenger rail network (Such investments also improve capacity for freight rail will provide capacity benefits for freight rail); and

- "Interregional Investment Corridors" in which the state is investing in rail as a strategy for ensuring capacity for goods movement, and addressing projected trucking volumes on parallel interregional highway segments. ${ }^{19}$

Similar to the passenger rail investment strategy, the plan outlines a phase freight rail investment strategy that is intended to promote the most efficient use of money by avoiding duplicate or stranded investments, while building towards identified long-term goals. ${ }^{20}$

${ }^{18}$ CA DOT "CA State Rail Plan” 171.

${ }^{19}$ CA DOT "CA State Rail Plan" 173.

${ }^{20}$ CA DOT “CA State Rail Plan” 174. 
Aligning the freight rail investment strategy with the vision for the state rail system outlined in Chapter 3, the CSRP the freight rail investment strategy identifies six major areas of need and opportunity (also referred to as categories of investment) for freight rail in California:

1. Trade corridor improvements.

2. Economic development and short lines.

3. Grade-crossing improvement needs throughout the state.

4. Additional terminal and yard capacity.

5. Short-haul rail improvements.

6. Advancement of zero and near-zero emissions technologies. ${ }^{21}$

Each investment category is explained at length on pages 175 through 181 in Chapter 5 of the CSRP. Additionally, the cross-modal benefits (freight/passenger rail) are identified.

The final section of Chapter 5 explains the relationship between the freight and passenger rail elements of the plan and how freight rail planning is different from passenger rail planning. The rationale is that, because the freight rail system is privately owned, decisions about the cost of the respective projects and investments will be based on customer demand and other conditions that do not require public disclosure. This is in contrast with passenger rail, which is substantially publicly supported and therefore requires high levels of transparency. Nonetheless, a set of projects that contain a freight rail element are contained in Appendix A of the CSRP. Their estimated cost, according to the CSRP, is between $\$ 20$ billion and $\$ 40$ billion. Together, these identified improvements, based on strategic and phased investment from public and private coordination, will increase the efficiency, reliability, and safety of goods movement in California and the United States. $^{22}$

Chapter 6 contains the proposed capital plan; federal, state, and local funding sources; program effects and guidance on the current and future rail studies and reports needed for the implementation of the 2040 Vision. Chapter 6 also explains how the 2040 Vision program will affect and benefit both the passenger and freight networks. ${ }^{23}$

Among the features and contents of the chapter is a fulsome description of the state's passenger and freight rail capital program and how it is integrated. Additionally, the chapter identifies sources for funding the integrated rail plans including operating costs funding, non-government funding sources, and federal, state, and local funding sources.

\footnotetext{
${ }^{21}$ CA DOT "CA State Rail Plan” 175.

${ }^{22}$ CA DOT "CA State Rail Plan" 182.

${ }^{23}$ CA DOT “CA State Rail Plan” 183.
} 
The chapter describes how the CSRP is benefitted by the state's 2040 Vision and various strategies for implementing the CSRP including the coordination of rail policies and plans, environmental policy, land use coordination, the use of public/private partnerships, and the impact of positive train control (PTC) on the operation of the state's rail system. ${ }^{24}$

The final chapter of the plan outlines both the strategies used to obtain public involvement in the development of the plan and the specific involvement and input of various stakeholder groups. These various stakeholder groups included a stakeholder advisor committee, representatives from other states bordering California as well states than are or may participate in a regional rail compact with the state, representatives of rail operating companies and agencies, representatives of freight rail companies, and representatives of Native American communities that are or could be benefitting from rail service.

The Draft 2018 CSRP was released in October 2017 for public comment and ultimately released on October 11, 2017, for a 60-day comment period. During the comment period, Caltrans held several workshops throughout the state attended by 350 people. Additionally, Caltrans held an online workshop attended by 200 people. In total. Caltrans received 626 public comments on the draft plan. ${ }^{25}$

The 2018 CSRP contains 33 tables and 48 exhibits.

Finally, California should be commended for being one of only a handful of states that recognized the potential impact of single-card payment systems. These payment systems combine multiple modes of transit across various agencies to enhance transit network connectivity. In addition, single-card payment systems are consumer friendly, customer-facing services that will provide public incentive for rail ridership, that may ensure growth and maintenance of all forms of public transportation.

The challenges facing California in the development of this plan are reflected in the fact that California is the world's fifth-largest economy, and home to nearly 40-million people. From the state's perspective, if it was to address the needs of its people, the critical nature of its environment, the ever-evolving technology — much of it created by California-based enterprises- the rail plan, and indeed the state's transportation vision, needed to be as comprehensive, inclusive, and forward focused as possible.

Additionally, because of its strategic position internationally, nationally, and regionally-both geographically and economically-California, through its CSRP, needed to position the state on many fronts and many issues that perhaps few other states either needed to, or would consider relevant to their priority needs over the next five to ten years.

${ }^{24}$ CA DOT "CA State Rail Plan" 184-236.

${ }^{25}$ CA DOT “CA State Rail Plan” 237-251. 
Moving beyond the overview of the state's rail plan and the purpose of the plan (Chapters 1 and 2), Chapter 3 of the CSRP presents both the enormity of the current California rail system, and identifies the trends and opportunities facing the state.

For example, the state's multimodal transportation system includes:

- $\quad$ Freight Switching Terminals - 275

Passenger Rail Route Mileage

- Long-Distance - 887

- Intercity Passenger Rail - 1,663

- Commuter and Regional Rail - 830

- Urban Mass Transit Rail - 382

- Highway/Roadway Mileage - 175,818

Airports

- Commercial Service Airports - 28

- General Aviation Airports - 215

- $\quad$ Special Use Airports - 68

Ports

- $\quad$ Seaports (Inland and Coastal) - 12

- International Ports of Entry - $6 .^{26}$

That said, there are several major gaps in the 2018 CSRP and most other states' rail plans. The most glaring gaps in state-level rail planning are related to the lack of progress measurement between previous and current iterations of state plans. The current CSRP does not indicate the level of progress that has been made with stated goals that have carried over from older CSRPs, decreasing the effectiveness of the plans themselves. On the same note, the CSRP is lacking methodology for determining how progress for the aspirations of future plans will be measured.

When reading the CSRP in the context of California's state transportation plan, it is difficult to identify the actual impact both passenger and freight rail have on various economic, mobility, and environmental goals as presented in the state's transportation plan. The lack of connection between rail plans and larger state goals is especially relevant, and potentially impactful on potential the level of funding available to build capacity and maintain the state's rail system. This is evident in

${ }^{26}$ CA DOT "CA State Rail Plan" 5. 
comparing California rail funding to the funding levels available to most other states, but especially when compared to highway and roadway expenditures.

Another area not addressed in the CSRP, but equally absent in other state rail plans, is discussion about infrastructure resilience, asset management, and state of good repair. Given natural disasters, overall wear and tear, and pandemics that have impacted the entire country in recent years, more attention must be given to these issues in order for the CSRP — and for that matter other state transportation plans - to be credible and viable, more attention must be paid to addressing these critical matters.

The bottom line for the CSRP-and for all state rail plans-is that aspiration is not a plan. Demonstrating achievement and measuring progress toward future goals will provide credibility and confidence in continued rail investment. In turn, this will enable intercity passenger rail, highspeed passenger rail, and all other forms of public transportation to justify the resources necessary to provide environmentally acceptable mobility options for passenger and freight movement in the $21^{\text {st }}$ century. 


\section{Summary of the Other Five State Rail Plans}

As noted in the first portion of this project, most states have rail plans that generally align with the "State Rail Plan Guidance" issued by the FRA in September 2013. The evolution of these plans dates back to the 1970s when the FRA administered a program that supported states in their efforts to plan for freight rail service on lines subject to abandonment.

According to Appendix C of the 2012 Colorado State Freight and Passenger Rail Plan (CSFPR), this program was known as the Local Rail Service Assistance (LRSA) program. Under the FRA, this program provided planning grants to states to develop their initial State Rail Plans and updates to those plans.

Over time, the content and competence of the states' respective plans has improved. In addition to the CSRP, the FRA staff also suggested that Colorado, Michigan, North Carolina, Virginia, and Washington be examined for their thoroughness. ${ }^{27}$

This section of the report looks at the scope and content of those five states rail plans and attempts to compare and contrast those plans with the CSRP. This comparison helps identify both the best practices and gaps that should be addressed in the next CSRP.

\subsection{The Colorado State Freight and Passenger Rail Plan: March 2012}

The Colorado State Freight and Passenger Rail Plan (CSFPRP) included all of the prescribed elements outlined in FRA's plan guidance. However, it also expands its scope and content to include massive amounts of statistical and historic data on the state's rail system. Additionally, it includes a comprehensive section outlining the plan's short and long-range investment program for both freight and passenger rail, rail plan policy recommendations, and strategy recommendations for integrating rail into the statewide transportation plan.

Among the plan's policy recommendations are strategies to:

- position Colorado for future federal funding for freight and passenger-related infrastructure improvements;

- explore new state and local funding sources for rail-related programs, infrastructure, and services;

- facilitate improved communication between communities and railroads;

- coordinate to ensure integration and connectivity with other existing and planned transportation system improvements;

${ }^{27}$ Will Dyer and Lyle Leitelt, Planning Staff, Personal/Phone Interview (Washington, District of Columbia, 2020). 
- embrace a performance-based evaluation process to coordinate rail alternatives into transportation corridor planning when appropriate;

- develop and explore implementation options for a regional commuter rail system;

- maximize use of existing infrastructure and monitor significant rail corridor infrastructure to ensure future corridor preservation and expansion;

- facilitate meetings among the Colorado Office of Economic Development, the Class I and short line railroads, regional economic development agencies, and representatives of various economic sectors such as agriculture, defense, tourism, and energy, to explore win/win opportunities to grow the Colorado and local/regional economies;

- develop and implement a Short Line Railroad Assistance Program;

- support linking of Colorado's passenger rail systems to the developing national intercity and high-speed rail networks; and

- use the Stakeholder Group convened for this Plan as a resource for the upcoming Interregional Connectivity and Advanced Guideway System studies and to advise on future updates to the Plan. ${ }^{28}$

In its description of the desired contents of Chapter 6 of a State Rail Plan, the FRA urges states to:

describe how the state coordinates state rail planning with other transportation planning programs and activities of the state and metropolitan areas, including those conducted under Section 134 and 135 of Title 23 and Sections 5303 and 5304 of Title $49 .^{29}$

The CSRP complied with this request at several points including in Chapters 3 and 4 and in Appendix A6. The Colorado Plan also addressed integration into the state's overall transportation plan primarily in sections $7-8$, suggesting that the intention was to promote modal integration more comprehensively in future rail plans.

The Statewide Transportation Plan is a corridor-based plan that integrates all modes of transportation into a vision for the transportation system of Colorado. As such, the State Freight and Passenger Rail Plan, along with other modal plans, will serve as an important component of the next update to the Statewide Transportation Plan. Similarly, it will serve as a vital document helping to inform the Regional Transportation Plans (RTPs) that comprise the Statewide Plan. ${ }^{30}$

Appendix $\mathrm{C}$ of the Colorado Plan offered two suggestions for best practices in rail planning. These suggestions included an interesting commentary on the evolution of transportation planning

${ }^{28}$ Colorado State Freight and Passenger Rail Plan (CSFPRP) (2012), 8-6.

${ }^{29}$ USC 49, Sections 134, 135, and USC 23, Sections 5303, 5304.

${ }^{30}$ Colorado State Freight and Passenger Rail Plan (CSFPRP) (2012), 221-235. 
through the various requirements of federal surface re-authorization acts. They also included an aspirational perspective that the current plan will serve as the basis of a more accountable, integrated plan in its next iteration:

This Plan is not the culmination of rail planning in Colorado; it is the beginning! With input from an extensive stakeholder outreach program, the Plan establishes a framework for effective freight and passenger rail planning within the state. CDOT and its broad array of rail stakeholders are committed to increasing the focus on improving freight and passenger rail transportation in the State and integrating rail planning efforts with those of other transportation modes. CDOT will also coordinate with other states to identify regional freight and passenger corridor needs and will work with the FRA and neighboring states to develop a Final National Rail Plan that it is consistent with this Plan. The ultimate objective will be to improve the mobility of passengers and freight within Colorado while enhancing the state's economy. ${ }^{31}$

In contrast to the CSRP, the Colorado Plan offered no suggestions for the measures or matrix of improvements of performance of the rail system or its integration with the overall state transportation system.

The question for both Colorado and California-as well as for other states-is how will decision makers and other stakeholders know when or what achievement and/or success will look like?

The Colorado Plan largely addressed how the rail system in the state is focused on providing through-put to destinations outside the state. The CSRP, however, focused on intrastate mobility with an awareness that mobility to destinations outside the state - and even connections to Mexico and Canada and to destinations across the United States - are critical to the growth and evolution of California's rail system.

Finally, the Colorado Plan contained an element called, "Task 1 - Summary of Best State Rail Planning Practices." It was an insightful discussion about how various states have attempted to address the myriad elements of the FRA State Rail Plan Guidance. Similar to most other plans, it did not address issues of how states should measure and demonstrate progress against earlier rail plans.

\subsection{The Michigan State Rail Plan - Final Report: September 2011}

In comparison to the CSRP, the Michigan State Rail Plan-Final Report: September 2011 (MSRP) - is now almost a decade old. It reflects a perspective and vision largely concerned with the dominance of freight rail at the time. It is also concerned with the early emergence of passenger rail (aside from limited Amtrak through the state). In that context, the MSRP is an aspirational statement that has enabled the slow but steady improvement in passenger rail service in the state.

\footnotetext{
${ }^{31}$ Colorado State Freight and Passenger Rail Plan (CSFPRP) (2012), 8.
} 
It has also enabled steady coordination with neighboring states to improve the through-put of both passenger and freight rail service.

The MSRP is impressive for its breadth of content, but the fact that the plan has not been updated since its publication in 2011 does raise questions about its viability. Its slow update also provides doubt concerning the degree to which the vision and aspirations reflected in the plan have been achieved and/or changed. The fact that FRA staff consider the MSRP to be one of the six best plans, suggests that there is something enduring about it even though it has not been updated or audited since its publication in 2011.

As noted in the executive summary of the MSRP:

The State of Michigan has a robust rail system that consists of both freight and passenger rail services. The rail system is an important component of Michigan's economy and will continue to evolve with state, national and global economic trends. The rail system has long played a significant role in the movement of freight in Michigan. According to the Freight Analysis Framework (FAF3), 33 percent of Michigan's overall freight tonnage was moved by rail in 2009; this accounts for approximately $\$ 41.4$ billion in commodities (in 2010 dollars). ${ }^{32}$

MSRP's Technical Memorandum \#1 (September 2010) identifies the vision and goals of the plan as:

The State Rail Plan envisions a rail system that provides enhanced mobility for travelers and the efficient movement of goods, while supporting economic development and environmental sustainability. This vision is supported by the following plan goals:

- promote the efficient movement of passengers;

- promote the efficient movement of freight;

- encourage intermodal connectivity;

- enhance state and local economic development;

- promote environmental sustainability; and

- promote safe and secure railroad operations. ${ }^{33}$

To its credit, even though the MSRP predated MAP-21 and the FAST Act, the plan ties directly to a long-range multi-modal transportation that has been updated in light of MAP-21.

\footnotetext{
${ }^{32}$ MDOT Draft MI Rail Plan (2011), 1.
}

${ }^{33}$ MDOT—State Rail Plan (2011), 4-7. 
The "Michigan Transportation Plan: Moving Michigan Forward-2035 State Long-Range Transportation Plan"- takes an interesting position on intermodal mobility, albeit heavily oriented toward freight and highway/roadway transportation.

Integrate the Transportation System:

Despite a substantial shortfall in funding for transportation infrastructure, there has been a surprising amount of progress in the intermodal integration of Michigan's transportation systems since the 2030 Michigan Transportation Plan (MITP) was issued in 2007. Fostered by economic necessity, agencies across the state worked to both reduce costs and derive the greatest benefit from every dollar invested. A new federal focus on issues such as livability and sustainability helped to accelerate the integration of transportation modes with each other and with surrounding land uses. In particular, the American Recovery and Reinvestment Act (ARRA) and the Transportation Investment Generating Economic Recovery (TIGER) grant program provided federal assistance that helped support many projects and programs that improved transportation integration in Michigan during the economic downturn.

More recently, the focus of state government under the leadership of Governor Rick Snyder has spurred efforts to integrate Michigan's transportation system with other government agencies. The Governor's Special Message to the Legislature on Health and Wellness in September 2011 increased the statewide focus on active transportation such as biking and walking. In October, the Governor's Special Message to the Legislature on Transportation and Infrastructure emphasized the increased need for funding for transportation, along with recommendations to improve regional coordination, consolidate transportation agencies, improve regional transit and passenger rail, and support continued efforts to construct a new Soo Lock and improve harbor dredging. ${ }^{34}$

New Policy Initiatives:

The desire to improve Michigan's economy, along with state and federal policy shifts, have furthered MDOT's efforts to integrate transportation systems since the 2030 MITP was released. Those efforts are reaffirmed through the 2035 MITP and will help bring Michigan closer to meeting the goals of Stewardship, System Improvement, Efficient and Effective Operations, and Safety and Security.

The list of new policies, programs, and initiatives aimed at integrating transportation systems in Michigan since 2007 is impressive. These new initiatives further the Preferred Vision of the longrange transportation plan and move the state closer to the goals established for Michigan's transportation network. Each of the department's actions and/or new policy initiatives are discussed in

${ }^{34} 2030$ MITP (2007). 
the New Policy Initiatives and Integration White Paper and address several of the 2035 MITP goals, while simultaneously continuing to advance integrated transportation in Michigan. ${ }^{35}$

Following adoption of MAP-21, Michigan began moving to use performance-based measures such as rail performance to develop the state's long-range transportation plans. An example of the Michigan performance-based score card can be found in the report. ${ }^{36}$

In October 2018, Michigan presented its current rail planning initiative that it intended to complete by the end of 2020 . The effort will produce an integrated perspective with three federally required plans in one:

- The State Long-Range Transportation Plan.

- The State Rail Plan.

- The State Freight Plan.

First of its kind in the country-in cooperation with federal agencies:

- The Federal Highway Administration (FHWA).

- The Federal Railroad Administration (FRA).

- $\quad$ The Federal Transit Administration (FTA).

Estimated completion: December 2020. ${ }^{37}$

This form of integrated planning is reflected in the CSRP. However, it is the performance measures that Michigan is now using in its long-range transportation planning that could be very helpful to California's future planning efforts.

\subsection{North Carolina Rail Division Comprehensive State Rail Plan: August 2015}

Similar to the rail plans of most other states, the North Carolina Rail Division Comprehensive State Rail Plan-August 2015 (NCSRP)_followed the formatting suggested in the FRA's September 2013 state rail planning guidance. Similar to many other state rail plans, the NCSRP linked to other ongoing statewide transportation plans and initiatives. It also identified the anticipated public benefits of additional rail investment. The plan has been used to help guide decision-making as the state invests in enhancements to the North Carolina passenger and freight rail system. North Carolina Department of Transportation (NCDOT) uses prioritization methods in the state rail plan to help evaluate projects and corridors. This process and the prioritized projects and corridors are periodically reviewed and updated to determine the effectiveness of the state's investment.

\footnotetext{
${ }^{35}$ MDOT 2035 State Plan (2012), 16.

${ }^{36}$ MDOT MI Scorecard (2019).

${ }^{37}$ MDOT (2019).
} 
Another key feature of the NCSRP is its link to the state's Strategic Transportation Investments (STI) program, which overhauled the state DOT's methodology for prioritizing and selecting capital expenditures. The data and projects listed in the NCSRP are evaluated and programmed on an ongoing basis under the STI. ${ }^{38}$

The plan's introduction noted that in addition to enabling the state to meet the FRA's eligibility requirements to receive federal grants, the purpose of the NCSRP was to:

- "establish the public vision for the state rail system and support the State's goals and policies to improve passenger and freight rail transportation;

- analyze and prioritize rail corridors, programs, and proposed projects;

- propose future improvements and investments, and assess funding options.

- provide a current inventory of the rail system and identify trends, markets, and needs;

- describe how programs managed by the NCDOT Rail Division work together with other government agencies, businesses and industries to deliver a comprehensive set of rail services that are integrated in the State's overall transportation system; and

- the NCSRP on its face is a very robust and progressive statement that anticipates the growth of the state and the concurrent demand for a robust, integrated, multimodal transportation system organized and operated around the mission of "safe and efficient movement of people and goods on North Carolina's railroads through freight, passenger and safety programs, supporting job creation and economic growth." 39

This mission was in line with the missions and goals of both NCDOT and the NCDOT Rail Division. It was also in line with the broader public policy goals for North Carolina former Governor Patrick McCrory's 25-Year Vision for North Carolina. His vision was a plan to help connect all North Carolinians with jobs, education, healthcare, and each other. Additionally, the plan was intended to stimulate and measure job growth and an overall positive economic impact for North Carolina.

The 25-Year Vision for North Carolina included a number of rail-related goals including:

- improve rail connections between military bases and ports;

- intermodal facilities to support freight shipping, and scheduled intermodal service to Port of Wilmington;

- improved rail access to Global TransPark and Port of Morehead City;

\footnotetext{
${ }^{38}$ North Carolina Department of Transportation Rail Division Comprehensive State Rail Plan (NCDOT) (2015), i.

${ }^{39}$ NCDOT (2015), 1-1.
} 
- economically competitive rail service to inland ports;

- improve rail and seaport connections to Interstate 95 to serve eastern United States (U.S.);

- expand access to passenger rail options in all regions of the state;

- expand mass transit options, including rail; and

- expand access to passenger rail options in all regions of the state. ${ }^{40}$

The NCSRP was also consistent with other statewide plans including the State Transportation Improvement Program, State Long Range Transportation Plan, and State Freight Plan. ${ }^{41}$

The state's long-range plans have addressed freight and/or passenger rail needs. The recent planning projects include the following:

- Eastern Infrastructure Improvement Study (2015), which assessed the impacts of strategic infrastructure investments in three of the state's transportation and economic assets- the Global TransPark, Port of Morehead City, and restoring the Wallace to Castle Hayne rail corridor.

- The risks, opportunities, and impacts of a variety of investments-including rail infrastructure and complementary facilities - were investigated to determine the financial feasibility and potential economic impacts of the investments.

- NC Maritime Strategy (2012), which investigated the role of the ports in the state's economy and the impacts of a range of opportunities that would result from investments in transportation infrastructure. The study also identified improvements for rail that would enhance the transport of goods at the ports and inland.

- Seven Portals Study (2011), which explored transportation infrastructure investments that would encourage economic development in potential logistics villages across the state. The study was aimed at the business community to demonstrate the state's readiness for commerce in a variety of industries to encourage job growth and support economic activity.

- Statewide Logistics Plan (2008), which developed a plan to address long-term statewide mobility needs by identifying priority commerce opportunities, recommending transportation infrastructure that would result in economic growth and outlined a timeline. Coordinating an economic development plan with transportation infrastructure investments was one of the recommendations.

\footnotetext{
${ }^{40}$ NCDOT (2015), 1-1.

${ }^{41}$ NCDOT (2015), 1-1.
} 
- State Rail Plans $(2001,2009)$ have previously identified priority rail corridors and recommended projects to improve freight and passenger rail in the state.

Under the Passenger Rail Investment and Improvement Act of 2008 (PRIIA), the FRA requires updates every five years to remain eligible for federal grant funds.

The NCDOT Rail Division also studied a potential passenger rail service extension to western North Carolina (Salisbury to Asheville) and to eastern North Carolina (Raleigh to Wilmington) and (Raleigh to Greenville). Additional information on these passenger rail plans and implementation of the Southeast Corridor are provided in the plan's Chapter $2 .{ }^{42}$

Ideally, North Carolina would be collaborating with Virginia to extend the Northeast Corridor south. The hope is that higher performing passenger rail service will eventually extend from Boston to Miami. ${ }^{43}$

Two contrasting features of the NCSRP and the CSRP are the intentions to use customer-facing technology (mobility as a service $(\mathrm{MaaS})$ ). While California outlines an aggressive strategy to pursue MaaS, North Carolina is silent on the subject. As for measurement of progress against the plan-North Carolina advocates for measurement and validation, but California is silent on the subject.

The NCSRP notes the remarkable growth of ridership and service of its passenger rail service since the 1990s, which is similar to ridership and service growth in California percentage wise. In addition, the plan takes note of its volunteer ambassador initiative that relies on riders being on-board advocates for the state's sponsored and Amtrak long-distance services. ${ }^{44}$

The net effect of North Carolina's efforts reflected in the "Program Benefits" section of the plan's first chapter, "The Role of Rail in Statewide Transportation," is that:

The planning and environmental work for the Southeast Corridor have helped identify the need for intercity rail in the Raleigh to Charlotte corridor and connecting to Washington, District of Columbia (D.C.) These efforts have led NCDOT to invest in constructing or renovating seven rail station improvements in the Charlotte to Raleigh corridor, and over $\$ 300$ million in track and signal improvements that have improved travel time, capacity, and the overall passenger rail service in North Carolina. Ultimately, ridership on the Carolinian and Piedmont trains has increased over 70 percent in the last nine years. The Rail Division has been awarded over $\$ 545$ million in competitive federal funds for rail improvements, in large measure because of the planning and project implementation efforts that have documented the needs and illustrated the benefits of the various rail projects in North Carolina. ${ }^{45}$

\footnotetext{
${ }^{42}$ NCDOT (2015), 1-12.

${ }^{43}$ Ibid., $1-21$.

${ }^{44}$ Ibid., 1-19.

${ }^{45}$ NCDOT (2015), 1-21.
} 
An interesting aspect of the NCSRP is the discussion of the Strategic Rail Corridor Network (STRACNET)—an interconnected and continuous rail line network consisting of over 38,000 miles of track serving over 170 defense installations across the nation. Similar to the vision President Eisenhower had for the Interstate Highway system, STRACNET was a creation for, and continues to support, the nation's defense and deserves federal and state support.

In terms of the state's intercity passenger and commuter rail services, North Carolina, similar California, relies on shared right of way with the Class I freight rails. However, unlike California, it has neither commuter service nor-at least for the present-is there effort underway to build a separate high-speed rail system. ${ }^{46}$

An interesting discovery in the North Carolina plan is the following provision:

Under Section 207 of the PRIIA, the State Rail Plan must include a performance evaluation of the passenger services operating in the state according to metrics established under PRIIA and by the FRA. The FRA publishes quarterly performance and service quality reports for all Amtrak routes using metrics established under Section 207 of PRIIA.33For the purposes of the evaluation of the routes serving North Carolina, most of the analysis will compare the Carolinian and Piedmont separately (state-supported services that serve most of the major population centers in the state) and other Amtrak train services (Crescent, Palmetto, Silver Meteor and Silver Star). ${ }^{47}$

This is the first plan reviewed in this project that specifically mentions this provision. It is also a provision that, as noted earlier in this paper, the FRA staff put special emphasis on. They would prefer that more states address this in their next round of planning. Even more interesting is the fact that this particular provision of PRIIA has resulted in a long-running legal battle between the Class I freight railroads and Amtrak. Congress has sought a resolution that will ultimately improve the on-time performance of intercity passenger rail service that operate on freight rail lines; however, the debate is not over.

Nonetheless, the North Carolina plan makes no projections regarding any matrix of performance. It only outlines performance as of the recent historic time frame reflected in the plan.

Similar to the CSRP, the NCSRP analyzes the economic impact of freight and passenger rail service in the state. However, neither plan attempts to project anticipated impact nor does either plan analyze economic impact since the last plan. ${ }^{48}$

As noted earlier, the NCSRP is a presentation of the current condition of the state's transportation system at the time the plan was prepared. It also presented the anticipated changes that may occur in the near future. What is missing from the NCSRP - as well as most other state rail plans-is

\footnotetext{
${ }^{46}$ Ibid., $2-11$.

${ }^{47}$ NCDOT (2015), 2-31.

${ }^{48}$ Ibid., 2-53.
} 
the measurement of progress from previous plans and the matrix for measuring progress going forward.

\subsection{Virginia State Rail Plan: 2017}

The Virginia State Rail Plan: 2017 (VSRP) is summarized in the lead paragraph of the plan's executive summary:

Virginia's rail network is a valuable asset that grows the economy, relieves congestion, saves lives, improves air quality and saves taxpayer money. Continued investment in rail infrastructure will ensure the mission and vision of the Commonwealth's transportation network is achieved. ${ }^{49}$

The state rail plan is tightly linked to the state's overall transportation plan, VTRANS2040:

The Virginia State Rail Plan recognizes Virginia's vision and DRPT's mission and provides a framework for achieving both of these desired future outcomes through investments in Virginia's rail network as part of a multimodal transportation system supporting economic growth. ${ }^{50}$

The VSRP follows closely the FRA 2013 Guidance. However, due to the state's location and geography, the its rail plan takes on an especially vital quality and importance to the current and future direction of the nation's transportation system. It is also a vital quality to the economic, demographic, and environmental progress of the nation. ${ }^{51}$

California and Virginia share similar but unique characteristics. These include:

- major national intermodal shipping facilities;

- gateway linkages to regional and national networks;

- have successfully engaged Class I railroads and other rail services to expand and improve capacity and service throughout their respective jurisdictions;

- have enjoyed growing significant growth in passenger rail ridership and introduction of new, profitable service to new and previously underserved markets;

- advanced planning and operations that address the role of both freight and intercity passenger rail as mobility options that also alleviate environmental and congestion issues; and,

- $\quad$ enjoy broad public support for planning, funding and advancing forward looking rail service. $^{52}$

\footnotetext{
${ }^{49}$ Virginia Department of Rail and Public Transportation (VDRP) (2017), 1.

${ }^{50}$ Ibid., 9.

${ }^{51}$ Ibid., 4.

${ }^{52}$ Ibid., 3-6.
} 
There are several goals in the VSRP.

The first is to optimize return on investments. Its objectives are to:

- leverage previous investments by supporting existing passenger services;

- enhance reliability for existing services;

- prioritize improvements to existing service corridors over service Target growing markets and make efficient use of the Rail Industrial Access Program funds;

- leverage public-private partnerships by prioritizing projects with matching funds;

- prioritize improvements to existing service corridors over service expansion capital projects;

- target investment where traffic, employment, population, or demand is expected to grow;

- target growing markets and make efficient use of the Rail Industrial Access Program funds;

- leverage public-private partnerships by prioritizing projects with matching funds;

- prioritize capacity investments that meet the needs of both the public and private sectors through enhanced data sharing; and,

- determine on a corridor-basis when rail is the most efficient mode to move people and goods. ${ }^{53}$

The second goal is to ensure safety, security, and resiliency by investing in projects that harness the safety benefits of moving people and goods. Its objectives are to:

- expand programs that support short line railroads in maintaining FRA Class 2 track safety standards;

- invest in projects that harness the safety benefits of moving people and goods by rail;

- prioritize critical infrastructure projects to reduce the risk of failure; and,

- $\quad$ support "State of Good Repair" projects. ${ }^{54}$

The third goal is the efficient delivery of high-quality projects and programs in a cost-effective and timely manner. Its objectives are to:

- update grant guidance annually and develop a grantee workshop to review program guidance and procedural updates;

\footnotetext{
${ }^{53}$ Virginia Department of Rail and Public Transportation (VDRP) (2017), 10.

${ }^{54}$ Ibid.
} 
- continually update DRPT grant management practices to ensure efficient administrative processes and project implementation;

- work with legislators and appointed officials to ensure policies are up-to-date and understood; and

- proactively identify projects and programs to support the DRPT mission. ${ }^{55}$

The fourth goal is to consider operational improvements and demand management first. It will do so by maximizing the capacity of the transportation network through increased use of technology and operational improvements before investing in major capacity expansions. These goals' objectives are to:

- encourage use of Intelligent Transportation Systems to improve operational efficiency;

- evaluate operations when considering investment in capacity to ensure the investment yields a lasting benefit; and,

- incorporate program criteria that prioritize low-cost improvements to relieve bottlenecks and provide capacity. ${ }^{56}$

The fifth goal is to ensure transparency and accountability and promote performance management. It will do so by working openly with partners and engaging stakeholders in project development and implementation as well as by establishing performance targets that consider the needs of all communities. The objectives of this goal are to:

- publicize application evaluation metrics and project data for rail funding programs;

- implement passenger rail station stop policy;

- develop program scorecards to measure impact of rail investments; and,

- market economic impact of rail investment. ${ }^{57}$

The sixth goal is to improve coordination between transportation and land use by encouraging local governments to plan and manage transportation-efficient land development. It will do so by providing incentives, technical support, and collaborative initiatives. The objectives of this goal are to:

- encourage local governments to support state funding decisions by making compatible investments and zoning;

\footnotetext{
${ }^{55}$ Virginia Department of Rail and Public Transportation (VDRP) (2017), 11.

${ }^{56}$ Ibid.

${ }^{57}$ Ibid., 12.
} 
- educate localities on appropriate land uses around both freight and passenger rail infrastructure;

- encourage local governments to support rail services with multimodal last-mile connections; and,

- integrate with and expand upon other state, regional, and local planning efforts. ${ }^{58}$

The seventh goal is to ensure efficient intermodal connections by providing seamless connections between modes of transportation. The objectives of this goal are to:

- prioritize rail projects that benefit the highway system and improve mode choice;

- enhance rail service to the Port; and,

- $\quad$ support "State of Good Repair" and capacity projects with short lines..$^{59}$

The eighth goal is to support local and regional economic development through its encouragement. It also aims to invest in the rail network. The objectives of this goal are to:

- promote the use of the Rail Industrial Access program through education and outreach with local economic development offices;

- work closely with Virginia Economic Development Partnership to attract rail conducive industries in accordance with the Code of Virginia;

- expand transportation options between regional markets through enhancements to passenger rail service; and,

- include input from local and regional freight railroads in economic development planning and initiatives. ${ }^{60}$

Of the state rail plans reviewed in this paper, Virginia's plan is most notable because it clearly sets forth specific goals and objectives. In particular, the fifth goal proposed creating score cards and metrics to measure the progress of the state in achieving the goals of the plan. This is a best practice that California and all other states should include in their future state rail and transportation plans.

In many ways, Virginia and California are very similar in their respective positions as major connecting points for international and transcontinental mobility. Virginia is positioned as the major connecting point between the northeast corridor and the emerging southeast corridor. This is the strategic point for freight both entering and leaving the United States on the East Coast.

\footnotetext{
${ }^{58}$ Virginia Department of Rail and Public Transportation (VDRP) (2017), 12.

${ }^{59}$ Ibid., 13.

${ }^{60}$ Ibid.
} 
Similarly, California_as much as it is a large geographic area in and of itself-is also a critical connecting point for mobility along the West Coast. This would include areas into Mexico and upwards to Canada as well as internationally from and into the United States. In addition, both states are experiencing huge new demands on the capacities of their transportation systems. Also, they are experiencing the introduction of innovative strategies for addressing those capacity challenges. These include the introduction of true high-speed passenger rail in California and the incremental improvement of speed, frequency, and communities served throughout the Commonwealth of Virginia.

\subsection{Washington State Rail Plan: 2019-2040}

The Washington State Rail Plan: 2019-2040 (WSRP) is an expansive, forward-thinking, and ambitious initiative. The plan seeks to position Washington State as the critical link between the U.S. and Canada, and from the northern transportation corridors of the U.S. into and out of the U.S. from transpacific markets.

Vision for Washington's Rail System

As an integral part of Washington's multimodal transportation network, the rail system provides for the safe, reliable, and environmentally responsible movement of freight and passengers to ensure the state's economic vitality.

The policy goals of the plan included:

- Economic Vitality: To promote and develop transportation systems that stimulate, support, and enhance the movement of people and goods to ensure a prosperous economy;

- Preservation: To maintain, preserve, and extend the life and utility of 184 prior investments in transportation systems and services;

- Safety: To provide for and improve the safety and security of 186 transportation customers and the transportation system;

- Mobility: To improve the predictable movement of goods and people throughout Washington, including congestion relief and improved freight mobility;

- Environment: To enhance Washington's quality of life through transportation investments that promote energy conservation, enhance healthy communities, and protect the environment; and

- Stewardship: To continuously improve the quality, effectiveness, and efficiency of the transportation system. ${ }^{61}$

${ }^{61}$ Washington State Department of Transportation (WSDOT) (2019), 7. 


\section{Performance Measures}

The rail performance measures described and evaluated in the WSRP are aligned with Washington State Department of Transportation (WSDOT)'s Practical Solutions Performance Framework. The Performance Framework supports six performance-based decision-making objectives and identifies measures for the six transportation policy goals. Sub-policies and measures have been identified for the mobility policy goal and are still under development for the other five policy goal areas.

The rail performance measures incorporated in this plan are aligned with the three sub-policies and measures for Mobility Performance Framework. These include:

- accessibility - where passenger rail multimodal connectivity analysis, presented in Appendix $\mathrm{B}$ of the plan, measures multimodal accessibility for Cascades stations and supports the accessibility sub-202 policy goal-;

- predictability - where on-time performance metrics for passenger rail services, presented in Chapter 4 of the plan, measures travel reliability and supports the predictability subpolicy goal; and

- efficiency-where rail system capacity analysis, discussed under Chapter 5, assesses system utilization and supports the efficiency sub-policy goal. ${ }^{62}$

As noted in Chapter 2 of the WSRP, the rail system in Washington consists of both freight and passenger rail elements. The freight rail system consists of an expansive network of main lines, branch lines, yards and terminals. The passenger rail system consists of long distance, intercity, and commuter rail services operating mostly on freight rail lines. ${ }^{63}$

Also noted throughout the WSRP is the fact that most of the railroad system in Washington is privately-owned. This is unlike roadway, transit, aviation, and water transportation systems that are generally owned and maintained at the public's expense and is accessible to any licensed operator. Rail carriers not only move the freight, but they commonly also own, maintain, and control the physical infrastructure functions as an integrated business. This includes marketing and pricing services, operating and dispatching trains, maintaining assets, and allocating capital for rolling stock and infrastructure.

The public sector's role in the rail system must be balanced with the needs and goals of the private railroad industry. Though the railroads work with the public sector to operate passenger rail service and to help plan necessary freight projects, it is nevertheless the responsibility of each railroad to make decisions about capital investments and maintenance spending. Railroads maintain their infrastructure assets to meet safety standards and to avoid expensive reconstruction. Railroads also

\footnotetext{
${ }^{62}$ Ibid.

${ }^{63}$ Ibid., 13.
} 
must consider which expansions of capacity will provide the most benefit to their business. The public sector interacts with private freight railroads in multiple ways. In general, overlap between public policy and private railroad decision-making occurs in five areas:

- publicly sponsored and publicly owned assets;

- taxation;

- grade crossings;

- $\quad$ rail safety; and

- economic incentives. $^{64}$

This is a very interesting perspective particularly in light of the earlier discussion regarding performance measure and planning for future demand:

More planning is needed to develop an intercity passenger rail system in Washington state that meets 1361 future demand. Plans are used to guide WSDOT activities, inform decision makers, and qualify for funding opportunities. This Rail Plan is not intended to provide detailed proposals for increasing passenger rail service. Further planning studies are needed to develop detailed strategies for reaching service goals. ${ }^{65}$

Another area where the state seems deferential to the privately owned railroad companies is in the discussion regarding resiliency. System resilience is the capacity of a system to absorb disturbance and retain its basic function and structure. For the rail system, these disturbances can be sudden (e.g., earthquake, flood) or can be more gradual, permanent changes (e.g., change in sea level) that affect rail infrastructure. Natural disasters like landslides, fires, volcanic eruptions, earthquakes, and flooding can affect rail operations in the state. Disturbances can be especially troublesome for the rail system, which has fewer and longer detour options than the highway system. Landslides are one of the most frequent natural disturbances that affect railroads in Washington. Railroads often can clear landslides to allow resumption of freight traffic movement in a few hours, but those delays can sometimes mean a shipment misses a connection. Passenger trains on BNSF lines are subject to a 48-hour moratorium after a landslide. Many landslide-prone slopes can be easily identified and some locations have recurrent slope failures, which can help focus preventative measures. Some historically stable slopes can suddenly fail. In those cases, land development at the top of the slope is often a factor leading to landslide issues. Climate change has the potential to increase the frequency and intensity of disturbances to the rail system. Washington has developed an integrated climate change response strategy, which identifies several potential risks to transportation infrastructure:

${ }^{64}$ Washington State Department of Transportation (WSDOT) (2019), 22.
${ }^{65}$ Ibid., 52. 
- sea-level rise and storm surge will increase the risk of major coastal damage, including temporary and permanent flooding of the rail system in low-lying areas;

- more intense downpours will increase the risk of flooding, erosion, landslides, and damage. Travel disruptions and delays could increase and seriously affect the state's economy and public safety;

- an increase in extreme heat could negatively affect rail tracks and other materials in the summer, but warmer winters could offer benefits from reduced road closures and snow and ice removal costs; and/or

- severe wildfires could cause temporary rail system closures and increased risk of erosion due to loss of vegetation, which stabilizes soil. ${ }^{66}$

\subsection{Washington's Integrated Rail System}

Chapter 5 of the WSRP summarizes the current capacity of its largely privately-owned rail system. It also points out some initiatives that are under consideration by both private and public interests to create new capacity that would support agglomerative relationships between communities emerging as a mega-region. Finally, it discusses the role the Washington State's rail system plays supporting mobility and economic vitality in its communities.

In Chapters 6 and 7, the WSRP paints a fairly optimistic perspective on how rail capacity will meet the forecast growth between now and 2040. However, the plan largely leaves the responsibility for capacity growth in the hands of privately-owned railroads and their potential partners. Additionally, there are no measurement tools to determine the success of these aspirational goals or how the state, through earlier plans, was able to measure previous successes or identify shortcomings of those plans.

This is a common feature of virtually every state rail plan, including California's Rail Plan. Similar to all other state rail plans, except California's Rail Plan, there is no discussion about mobility as a service (MaaS) or the concept of one payment medium for all modes of transportation. It will be interesting to see how Washington and other states will address this issue in coming iterations of their state rail plans.

To its credit, however, the emerging RailPlus program allows Sound Transit passengers to use Amtrak Cascades trains at Seattle's King Street Station, Edmonds and Everett Stations by purchasing an Amtrak RailPlus ticket. Tickets can be purchased with an ORCA card, ORCA Passport card, or at the regular Amtrak ticket rate. Likewise, Amtrak Cascades ticketholders can ride

${ }^{66}$ Washington State Department of Transportation (WSDOT) (2019), 77-78. 
designated Sounder trains between Seattle and Everett at no additional charge. This opportunity strengthens both services. ${ }^{67}$

Most telling about the WSRP — and virtually every other state's plan —is that the "State Rail Plan is meant to guide and inform public investment and action on the rail system, highlighting critical needs facing the system and outlining recommendations to address them." ${ }^{\prime 6}$

The questions for each state are:

- How will they determine success?

- How will they measure it? and

- How will they know what do if the plan does not produce desired results?

${ }^{67}$ Washington State Department of Transportation (WSDOT) (2019), 71-72.

${ }^{68}$ Ibid., 111. 


\section{Comparison of California State Rail Plan with Others}

As noted throughout this report, the FRA, as directed by Congress and enacted into law, published guidance for states to develop State Rail Plans in order to be eligible to receive funding for a variety of improvements and opportunities. In addition, through a series of surface transportation reauthorization acts, states have been directed to incorporate their rail plans into their state transportation plans. This reflects the recognition that rail is a key element of the entire transportation infrastructure of states, regions, and the nation.

In Chapter 1, the desired format of the state rail plan was presented along with the intentions of Congress and the efforts of the FRA to meet its congressional mandate. As a result, in 2013, the FRA issued guidance to the states to submit periodic five (now four-year plans) in the following format:

Executive Summary

Chapter 1: The Role of Rail in Statewide Transportation (Overview)

Chapter 2: The State's Existing System

2.1 The State's Existing Rail System: Description and Inventory

2.2 The State's Existing Rail System: Trends and Forecasts

2.3 The State's Existing Rail System: Rail Service Needs and Opportunities

Chapter 3: Proposed Passenger Rail Improvements and Investments

Chapter 4: Proposed Freight Rail Improvements and Investments

Chapter 5: The State's Rail Service and Investment Program

Chapter 6: Coordination and Review

Technical Appendix: Documentation of Technical Assumptions and Procedural Steps

In Appendix A of this paper, the content of each state's rail plan on record with the FRA in April 2020 was profiled again against the FRA's guidance format. As the appendix shows, many state plans reflected the exact guidance outline. Several states included additional chapters and multiple appendices. Only two states provided plans that did not address passenger rail investments or facilities. This is presumably because there is minimal interest or use of passenger rail service in those states and/or those states have minimal interest in pursuing federal funding for passenger rail.

Chapter 2 contains a summary of the latest CSRP. Chapter 3 contains a summary of five statesColorado, Michigan, North Carolina, Virginia, and Washington-and a comparison of each of 
those states' rail plans with the CSRP. Chapter 3 also identifies the gaps and suggests best practices that California may wish to address in future rail and STPs.

One of the more interesting discoveries in reviewing the various State Transportation Plans (STPs) was that Colorado included in its Appendix $\mathrm{C}$ a discussion of state rail planning best practices. This appendix provided a history of state rail planning efforts dating back to the 1970s, with heavy emphasis on the establishment of rail advisory bodies and the outreach efforts of states to obtain input from the various stakeholders.

The Colorado document also addressed "Rail Vision"-where the state wants to go regarding freight and passenger rail as well as the most appropriate paths to get there-noting that Iowa and Arizona reflect the best practices for short and concise versus longer and more detailed visions.

Myriad other issues addressed in the FRA guidance were also addressed in the Colorado appendix. These included rail system inventory, rail issues and opportunities, needs identification, project evaluation, and funding for project implementation. Similar to the FRA guidance - and to most state rail plans - there is no discussion of matrix or evaluation of progress made by states against the aspirational expressions of previous plans. It also does not address new technologies or matters such as state of good repair, asset management, or system resilience. 


\section{Academic Literature Review}

A review of academic literature revealed ample research supporting the enhancement and expansion of regional rail networks in a manner consistent with the main components of the FRA "State Rail Plan Guidance." ${ }^{69}$ These main guiding components include connectivity of rail infrastructure to other state infrastructure, connecting rail networks with consumers and end-users, environmental impact of rail operation and expansion, and economic impact of rail investment. These areas of focus align with those identified in a comprehensive study of 51 statewide, long-range rail transportation plans by the Volpe Center, which can be viewed as "best practices" in regional rail planning.

\subsection{Connectivity of Rail and Other State Infrastructure-Freight}

Much of the literature covered acknowledges the significant contribution of freight rail to a state's rail infrastructure and operations. Meyer advocates for freight movement to be further integrated into the transportation planning process, specifically the need to increase intermodal connections between cargo ships, freight rail, and trucking. ${ }^{70} 50 \%$ of freight rail cargo is coal and chemicals, indicating an additional need for collaborative planning with state energy planning. Increased freight rail movement increases freight train length. In turn, this impacts vehicle traffic flows at at-grade intersections and conflicts with commuter trains' schedules, many of which run on the same tracks.

Meyer and others highlight the need for public policy to include freight-related impacts as a criterion for analysis of commuter rail planning. Zyngier et al. applied mathematical models to optimize railway scheduling between freight and commuter rail. ${ }^{71}$ This application allowed railway authorities to determine the maximum capacity of a rail system and to identify areas of a rail network where capital investment can be prioritized. Bucklew presents research to support major rail infrastructure investment in the Midwest. ${ }^{72}$ This research created an adjacent freight rail system designed to bypass major rail bottlenecks, such as in Chicago, but was still accessible to major commercial hubs to disperse trucking impacts.

The California State Rail Plan (CSPR) anticipates a doubling of freight rail movement by 2040. It required shared investment in freight and passenger rail, infrastructure improvements, coordinated planning between state and local agencies, and multimodal connectivity. Michigan's "State Long-Range Transportation Plan" highlights current freight rail movement in the state, seeking

\footnotetext{
${ }^{69}$ FRA "State Rail Plan Guidance."

${ }^{70}$ Michael D. Meyer, Transportation Planning Handbook by ITE (Institute of Transportation Engineers) (2016), pp. $15,22,39$, and 52.

${ }^{71}$ Danielle Zyngier, Jan Lategan, and Ludwig Furstenberg. "A Process Systems Approach for Detailed Rail Planning and Scheduling Applications," (2017), 273-280.

${ }^{72}$ K. Bucklew, "The Heartland Fast-Freight Rail System," in Transportation Journal (2007), 36-41.
} 
to embrace intermodal connectivity as a means to stimulate opportunity for growth. Virginia's "VTRANS 2040 Freight Plan" discusses rail specifically from a freight perspective, examining current conditions, needs, and strategies for intermodal connectivity.

\subsection{Connecting Rail to Consumers and End Users}

In its goal to connect multiple areas across long distances, regional rail planning is naturally seen through a large-scale lens. However, as much of the literature indicates, success in regional rail planning requires the analytical lens to shift to a more human-scaled focus. This would help to understand how benefits of rail growth are perceived by key stakeholders including individual consumers.

In discussing the reemergence of the British freight rail industry, Haywood discusses the necessary role of rail planning initiatives to mitigate the negative impacts of rail infrastructure on communities. $^{73}$ The research suggests a simultaneous and strategic approach to articulating the regional benefits of freight rail growth. To improve passenger rail planning approaches, Sperry and Collins analyzed survey data from five different intercity passenger routes. ${ }^{74}$ This analysis unveiled socioeconomic diversity in ridership populations and the opportunity to capture more business-related travel. This is the only paper amongst the literature reviewed that explicitly discusses equity in rail accessibility and calls for increased train frequency along with improved first and last mile transit.

Shepherd and Pryke conducted qualitative analysis through semi-structured interviews in order to study the importance of communication discourse and social networks in regional rail planning in Scotland. ${ }^{75}$ Their findings demonstrate the benefits of collaborative planning between stakeholders, which enables direct communication, trust, and the ability of parties in "asymmetrical power relations" to be "steered" to common goals. Mees provided an overview of the planning process for the Melbourne Metro and regional rail link in Australia. ${ }^{76}$ Here, major oversights related to the lack of transparency of the project and poor public engagement in the planning process.

Nicolaisen, Olesen and Olesen discuss the role of light rail development in Denmark as a means to increase branding value. ${ }^{77}$ Light rail development would also become a positive image for public transportation and be socially accepted as a means to reduce road congestion-stimulating overall

\footnotetext{
${ }^{73}$ R. Haywood, "Rail-Freight Growth and the Land Use Planning System," The Town Planning Review (2021), 445-467.

${ }^{74}$ Benjamin R. Sperry and Tyler Collins, "Improving Intercity Passenger Rail Planning Using Evidence from Passenger Survey Data," (2018), 234-244.

${ }^{75}$ Richard K. Shepherd and Stephen D. Pryke, "Regional Rail Planning; A Study of the Importance of 'Steering' and 'Pragmatism' in Stakeholder Networks," European Management Journal (2014), 616-624.

${ }^{76}$ Paul Mees, "Planning for Major Rail Projects: The Melbourne Metro and Regional Rail Link," (2010), 15-17.

${ }^{77}$ Morten Skou Nicolaisen, Mette Olesen, and Kristian Olesen, "Vision vs. Evaluation - Case Studies of Light Rail Planning in Denmark," (2017), 5-15.
} 
urban development. Their qualitative approach to implementation allowed for unique spatial visualization of transit infrastructure and promoted travel mode shift to rail. Neidzielski and Melecki explore this concept of branding by examining express rail connectivity to airports in cities across the globe. They equate these systems to placemaking efforts, evoking a positive image of a city and a sense of pride in their transit infrastructure by residents and visitors. ${ }^{78}$

The CSRP anticipates an increase of rail trips in California by ten times with twenty times the mode shifts from other means of transportation to rail. A statewide common fare system, as well as coordinated scheduling, is presented as a means to optimize rail for riders. North Carolina's Statewide Transportation Plan suggests that passenger rail is experiencing consistent growth. This growth can be partially attributed to volunteer ambassador initiatives which place individuals on trains as on-board advocates to promote the values of rail travel.

\subsection{Environmental Impact of Rail}

As an efficient means of transporting people and commercial freight, rail services are understood to be a more environmentally friendly alternative to vehicle travel and truck delivery. Chaudhury conducted research on converting roadways to rail between urban centers in India. This research focused on emissions and energy usage. He concluded that rail was more energy efficient and resulted in fewer emissions in all but one measure: displaying the environmental benefit of mode shift in freight movement and passenger travel. ${ }^{79}$

In his book, Tumlin offers best practice suggestions for sustainable transportation planning. ${ }^{80}$ His chapter on rail development highlighted the ability of rail investment to draw private development funding, encourage denser land uses, and help reduce vehicle miles traveled and GHG emissions. These concepts are exemplified in a study of Los Angeles rail corridors by Houston et al. In this study older, denser corridors saw increased transit use over newer corridors, which required careful consideration of urban design. ${ }^{81}$

Resiliency of rail infrastructure is a common concern that academic literature seeks to understand through various modeling techniques. The literature focuses mainly on safety concerns and mitigating economic risks. Verma, Verter, and Gendreau developed a model to assess the associated economies of risk involved with increasing capacity of hazardous material transportation in the

\footnotetext{
${ }^{78}$ M. Niedzielski and E. Malecki, "Making Tracks: Rail Networks in World Cities," Annals of the Association of American Geographers (2012), 1409-1431.

${ }^{79}$ Prosenjit Dey Chaudhury, "Rail and Road in Intercity Transport: Energy and Environmental Impact," Economic and Political Weekly (2003), 4423-4425.

${ }^{80}$ Jeffrey Tumlin, Sustainable Transportation Planning (New Jersey: Wiley Books, 2012), 105-107.

${ }^{81}$ D. Houston, M. Boarnet, G. Ferguson, and S. Spears, "Can Compact Rail Transit Corridors Transform the Automobile City? Planning for More Sustainable Travel in Los Angeles," Urban Studies (2015), 938-959.
} 
Midwestern U.S. ${ }^{82}$ The model improved tactical planning approaches by reducing potential population exposure while maintaining realistic operating costs. Greenberg et al. modeled realistic rail disaster scenarios between New Jersey and New York, producing accurate results that can enable planners to adequately prepare for a variety of rail-related hazards. ${ }^{83}$ Mitra and Bezbaruah created an adaptable model based on new rail infrastructure in an environmentally sensitive area of Assam, India. This model assessed the impact of rail infrastructure on ecosystems and, thus, viability for the project. ${ }^{84}$

The CSRP aligns with the overall desire of state and local general plans to reduce GHG emissions and improve air quality through vehicle to rail mode shifts and electrification of rail fleets throughout the state. The Washington Transportation Plan 2035 focuses greatly on resilience planning for its rail infrastructure. It applies scenario planning techniques to be prepared for landslides, flooding, and wildfires in the state.

\subsection{Economic Impact of Rail}

Economic implications of rail development and investment are of significant interest to regional rail planners. This is reflected in the ample amount of literature that discusses funding, development, and connecting economic regions through high speed rail. Meyer details statewide transportation planning best practices. ${ }^{85}$ The research points out the value retention of rail projects which provide economic justification for rail expansion. He lays out state rail plan elements in PRIIA, emphasizing the need for coordinated planning, including partnerships with private entities to ensure funding for projects. Rutzen et al. conducted a case study of suburban commuter rail connection to Metro services in Mexico City, Mexico. ${ }^{86}$ They attribute that project's success to the careful coordination at various levels of government, public-private partnerships, and transparency in implementation, ensuring the project was adequately funded through all its phases.

Ross discusses rail expansion in the U.S. in relation to the global economy. His research suggests that high speed rail is crucial to the continued economic growth and competitiveness of "megaregions" with over ten million people. ${ }^{87}$ Todorovich expands on this scale of development

${ }^{82}$ M. Verma, V. Verter, and M. Gendreau, "A Tactical Planning Model for Railroad Transportation of Dangerous Goods," Transportation Science (2011), 163-174.

${ }^{83}$ Michael Greenberg, Paul Lioy, Birnur Ozbas, Nancy Mantell, Sastry Isukapalli, Michael Lahr, Tayfur Altiok, Joseph Bober, Clifton Lacy, Karen Lowrie, Henry Mayer, Jennifer Rovito, "Passenger Rail Security, Planning, and Resilience: Application of Network, Plume, and Economic Simulation Models as Decision Support Tools," (2013), 26.

${ }^{84}$ S. Mitra and A. Bezbaruah, "Railroad Impacts on Wetland Habitat: GIS and Modeling Approach," Journal of Transport and Land Use (2014), 15-28.

${ }^{85}$ M.D. Meyer, Transportation Planning Handbook by ITE (Institute of Transportation Engineers) (2016), 11.

${ }^{86}$ B. Rutzen, Nathan Hutson, and Lisa Loftus-Otway, "Mexico City, Mexico, Commuter Rail: Planning and Implementation of Multijurisdictional, Public-Private Partnership Project," (2018), 119-126.

${ }^{87}$ C. Ross, "Transport and Megaregions: High-Speed Rail in the United States," The Town Planning Review (2011), 341-348. 
by planning on the megaregion level. He envisions a network of megaregions, connected by high speed rail, that are linked by natural systems, settlement patterns, and complementary economies. ${ }^{88}$

Schwieterman and Scheidt used survey data to assess high speed rail planning efforts in the U.S. They determined that significant funding was required to obtain right-of-way land for rail infrastructure. ${ }^{89}$ Secured funding would enable partnerships with freight railroads and incentivize corridor expansions, making them more financially viable for stakeholders. Mathur and Srinivasan take a practical approach to high speed rail planning. They assessed a specific corridor of the Midwestern United States for potential high-speed rail implementation. ${ }^{90}$ To propose this project as part of a national high-speed rail network, the authors identified funding sources, suggested partnerships with private railroads, established clear benefits of high-speed rail, developed strategies for gaining political support, and identified relationships with intermodal services.

The CSRP explicitly states that the motivation for building a high performance, statewide rail system is to remain competitive in the global economy. Expanded rail infrastructure would also spur economic growth through increased development, freight movement, jobs, and taxes. The Colorado "Statewide Transportation Plan 2040" discusses the need for a multimodal transit system to meet growing travel demand in the state. However, it concedes that its current interregional rail system is very limited. Future funding is limited as well, compromising the ability of the plan to embrace rail projects.

\subsection{Summary}

A review of the literature discussing statewide rail planning supports the overall objectives of the California State Rail Plan-relating to freight rail connectivity, end-user connectivity, environmental impacts, and economic impacts.

The CSRP greatly emphasizes the need to increase freight rail capacity in the long term. This would increase intermodal freight connections, create new infrastructure grade, separate where needed, plan freight and passenger rail operations concurrently, and understand the materials and industries that utilize freight rail services.

The end-user experience for rail services, from consumer to private investor, is acknowledged in many ways by the CSRP. The plan estimates a majority of trips will shift modes to rail by 2040. This shift would offer plans to integrate different rail systems into a single payment plan as well as synchronize interregional train schedules. However, there are many opportunities identified in the

\footnotetext{
${ }^{88}$ P. Todorovich, "Megaregion Planning and High-Speed Rail," in C. Montgomery, Regional Planning for a Sustainable America: How Creative Programs Are Promoting Prosperity and Saving the Environment (New Brunswick, New Jersey, London: Rutgers University Press, 2011), 261-267.

${ }^{89}$ Joseph P. Schwieterman and Justin Scheidt, "Survey of Current High-Speed Rail Planning Efforts in the United States," (1995), 27-34

${ }^{90}$ S. Mathur and S. Srinivasan, "High-Speed Rail in the Midwest United States: Potential for Success," Theoretical and Empirical Researches in Urban Management (2009), 59-74.
} 
literature for bolstering rail service that were not addressed. This leaves questions as to how this mode shift will actually take place.

Support for rail projects in CSRP align with the goals of sustainable planning to minimize environmental impacts on the state. The CSRP seeks to reduce greenhouse gas emissions, utilize rail corridors more effectively and efficiently, invest in resilience against natural disasters, and consider the unique landscape of California in future plans—-such as the preservation and connectivity of Tribal lands.

The CSRP advocates for a robust rail network as a means of maintaining a competitive economic edge. It also underscores the value of rail infrastructure that connects to a national network. Rail investment should include private-public partnerships as a means to capitalize on market driven opportunities. CA High-Speed Rail embodies these notions of competitiveness and unique private-public partnerships. Successful, large scale rail projects require significant funding, political support, and coordination between all levels of government. This fact is well conveyed in the CSRP; however, no roadmap is provided to facilitate this difficult process. 


\section{Recommendations for the Next California State Rail Plan}

In general, California produced a very solid rail plan that lays the groundwork for future measurable plans that have the potential to be highly integrated with the state's regions and national multimodal transportation plans. The California Rail Plan also has features that include mobility as a service (MaaS). California was one of only a handful of states that recognized the potential impact of single card payment systems. These systems combine many modes and various other activities and amenities as consumer friendly, customer-facing service that will provide incentives to ensure potential growth and maintenance of all forms of public transportation. In the meantime, in order to improve the next California rail plan, we make the following recommendations based on the reviews and comparisons in the previous chapters:

\subsection{Measurement}

As noted in earlier chapters of this report, both the FRA and many states take a light touch to setting measurable goals for the performance of their rail infrastructure. There is only the exception of on-time performance of passenger and freight rail service, which has been the subject of legislative, regulatory, and judicial deliberations.

The rationale for this light touch is grounded in the fact that most of the nation's rail infrastructure is privately-owned. Nonetheless, there are significant examples of states (e.g. Virginia, California, Michigan, and Wisconsin) where collaboration between the state and the private sector are producing potentially significant improvements.

However, in both the legislative mandate for state rail planning and the regulatory guidance for those plans, there are major gaps that significantly limit the value and impact of these planning efforts. For example, there are no metrics that track the progress of any states' effort from the aspirational expressions of earlier plans to the aspirational expressions of the most recent plan. There are also no metrics that set goals to be addressed in future plans.

How are decision makers to know what success is or looks like? As a result of MAP-21 and the FAST Act there are means by which MPOs and states can prioritize infrastructure projects by their perceived ability to reduce congestion. However, there are no measures for addressing economic impact, improved mobility, or the sustainability of the infrastructure-to name a few.

Clearly most state plans expressed aspirational goals regarding GHG reductions. However, this is not the only measure of an effective rail plan. Another measure that is attracting increased attention is equity. While the word may mean many things to many people, presently it can be measured indirectly based on several performance metrics. These metrics include accessibility (e.g., how the 
rail service is accessible to different groups of people at different regions), affordability (e.g., how the rail service is affordable to different groups people with different income), technology use (e.g., how the people of different age and income can use the technology required by the rail service such as making ticket reservations on internet), and language use (e.g., how people of different ethnic groups understand English or whether any other language is available to customers to use the rail service), among others.

It is difficult to identify the actual impact both passenger and freight rail plans will have on various economic, mobility, and environmental goals if we read the CSRP in the context of the state's transportation plan. This is especially true with regard to the level of funding available to build capacity and maintain the state's rail system compared to the funding levels available to most other-but especially highway and roadway-infrastructure.

The bottom line for the CSRP — and for that matter all state rail plans - is that aspiration is not a plan. Demonstrating achievement and measuring progress toward future goals will provide credibility and confidence. In turn, this will enable intercity passenger rail, high-speed passenger rail, and all other forms of public transportation to be able to justify the necessary investment of resources. These measures of success will position the state to further pursue federal funding through performance-based grants, providing environmentally acceptable mobility options for passengers, and freight movement in the $21^{\text {st }}$ century.

\subsection{Resilience}

Another area not addressed in the CSRP, but equally absent in other State Rail Plans was discussion about infrastructure resilience, asset management, and state of good repair. Given the nation's experience over the past 20 years, in order for state rail plans - and for that matter state transportation plans - to be credible and viable, more attention needs to be paid to addressing these critical matters. This would include measurements from the federal government, states, and service providers in future rail and state transportation plan strategies, standards, and measurements in order to effectively address these challenges.

There must be a measure for high-priority concern over the resilience of the rail infrastructure. Recent natural disasters and the various emerging and ongoing pandemics suggest that the federal government, states, and service providers need to be more proactive to ensure and demonstrate high levels of state of good repair. This would include performance levels for asset management and resilience.

\subsection{Parallels to the Interstate Highway System}

Advocates for improved intercity and high-speed passenger rail, as well as improvements to the nation's freight rail system, rarely mention the strategic importance of rail to the nation's defense. 
North Carolina, however, in its rail plan discussed at great length the Strategic Rail Corridor Network (STRACNET) — the 36,000 miles of rail lines throughout the United States that help deliver defense materials and personnel to 120 military and other key strategic facilities. ${ }^{91}$

In discussing the success of the Interstate Highway system, proponents frequently point to President Eisenhower's 1954 State of the Union message to Congress in which he proposed an American interstate highway system that he justified as a national defense program. "The highways could be used for transporting troops and for evacuating cities in case of nuclear attack." ${ }^{\prime 2}$

Passenger rail proponents also give significant credit to President Eisenhower for masterminding this achievement based on his experience in World War II and before. However, Eisenhower was not a singular-mode advocate. During his tenure as president, he advanced several modes of transportation including rail. This ultimately led to the deregulation of rail service that would follow more than 20 years after President Eisenhower left office.

The role of the states and the interests of the federal government still frame the debate over the role of federal funding in supporting intra and interstate rail passenger service. As the states and the federal government address the renaissance of freight and passenger rail in the United States, there remains many policy and opportunity gaps at play. This is especially true since there are a vast array of economic, environmental, and other national interests at play-not unlike those that framed the policies that led to the creation of the Interstate Highway System.

\subsection{Innovative Rail Funding and Financing}

States such as California, Colorado and Virginia are using a wide range of strategies to fund and finance the development and improvement of rail service. Private/public partnerships, the use of private activity bonds and various tax schemes, and direct government appropriations, are bringing badly needed resources to advance rail projects throughout the U.S. Since most American rail service operates on networks owned by private interests, the current debate centers around ensuring there is adequate capacity to maintain current service and the necessary resources to expand capacity.

Issues that concern benefits/costs and returns on investments are critical to determine both the maintenance of current levels of service and development of new capacities. Yet, little discussion or measurement of impact of the wide range of funding and financing mechanism is presented in the respective state rail plans - or for that matter the respective state transportation plans. In order for the public and policy makers to understand the ramifications of various funding and financing scenarios, more evaluation and greater analysis needs to be included in future planning efforts.

\footnotetext{
${ }^{91}$ US Army "Railroads for National Defense."

${ }^{92}$ US Senate "Federal-Aid Highway Act."
} 


\subsection{Decision-Making Frameworks and Tools for Future System Performance}

The decision-making challenges facing state transportation agencies are becoming increasingly complex. Their complexities increase as a result of working to develop strategies to ensure rightsized, high performing, and sustainable transportation systems that also support robust economic growth. Rapidly changing technology, emerging energy sources, and climate and resiliency issues are only a few of the factors with which transportation leaders must wrestle when setting goals and making investment decisions. Punctuating these challenges are the complete perturbation of transportation systems and decision-making due to COVID-19. Service disruptions, travel restrictions, and resources impact all aspects of decisions for future system performance.

Future transportation systems will be judged based on their ability to deliver services efficiently, equitably, and sustainably while supporting economic growth. Yet the ability of any organization, particularly state transportation agencies, to predict the future over the next several decades is confounding. The list of issues, framed by TRB in CIT2019, is daunting. Some of the factors lend themselves to quantification and forecasting using industry metrics and methodologies. These include performance measures related to population, economic factors, trip-making, asset condition and performance, life cycle benefits and costs, equity, and safety. Other issues are more difficult to predict or quantify, such as future technology, energy, sustainability, resiliency, workforce capacity, and governance and institutional frameworks.

To ensure that future efforts assist state departments of transportation and other transportation agencies with strategic decision-making, plans must address future trends and changing goals. They must also make recommendations regarding:

- new definitions and standards for system performance;

- frameworks for decisions needed to optimize performance;

- a catalog of information and tools that can be used within those frameworks to achieve high performance.

\subsection{Establish State and Regional Rail Advisory Bodies}

According to the FRA's state rail planning guidance from 2013, the Passenger Rail Investment and Improvement Act of 2008 (PRIIA) requires states to establish or designate, by state law or the direction of the Governor, a "State Rail Transportation Authority" (SRTA). The SRTA is a State agency or official responsible for preparing, maintaining, coordinating, and administering the State Rail Plan. Usually, the SRTA is the State Department of Transportation. The SRTA establishes priorities and implementation strategies to enhance rail service in the public interest and works to ensure that the State Rail Plan fully reflects the state's policy on freight and passenger rail transportation, including commuter rail. 
PRIIA also requires states to establish or designate a "State Rail Plan Approval Authority" (SRPAA), with responsibility to review and approve the State Rail Plan. The SRPAA serves as the State approval authority for investment of public funds in rail projects. In most cases, the State Secretary of Transportation is designated as the authority that provides the final approval of the State Rail Plan. As with the SRTA, states have flexibility to designate the most appropriate official or organization within their state government as the SRPAA. It is possible for the SRTA and SRPAA to be the same state entity or official.

While many states have taken such steps, several have not. For those states that have established such bodies every effort must be made to ensure that the work of these authorities is fully transparent and that they provide regular reports to their legislative oversight committees and to the general public. Additionally, every effort must be made to obtain input from the various stakeholders, as California, Colorado, Virginia, and Washington state have done.

\subsection{Periodic Review of Rail Plan Implementation}

Revised FRA guidance requests that states update their rail plans every four years. In reviewing the respective state plans for this study, it was observed that several states' rail plans are over 10 years old, while other states are more current. California, for example, is currently in the process of updating its plan with an eye toward publishing a revised plan within the next year.

While preparing this study, a reoccurring comment made by some state agencies was that they are so busy preparing plans they don't have time to implement them. The bottom-line objective of planning is to develop and implement strategies that can be easily reviewed and successfully implemented and produce measurable results. North Carolina and Virginia seem to be leaders in this regard with many states making considerable efforts to improve their performance.

\subsection{Active Outreach}

Public support is crucial to the advancement of rail initiatives in California, whether it is the planning and construction of major rail infrastructure or the implementation of new rail services and features. Publicly expressed desire for improved rail options leads to the prioritization of rail projects by policy and decision makers. These officials are called upon to approve rail projects and, where necessary, provide public funding and create financing mechanisms.

The state should increase efforts to actively create dialogue with the general public and to communicate its future rail plans. This would improve transparency and help educate a car-reliant public on the benefits of rail transit. Expanding outreach efforts to the public will provide opportunities for feedback. Additionally, encouraging increased participation in the rail planning process would improve and strengthen rail initiatives. These efforts would also enhance communication methods between transit agencies and stakeholders across the state to optimize coordination and efficiency in implementation. 


\subsection{Support Ongoing Caltrans Initiatives}

The CSRP initiatives and strategies that were reviewed in this paper were published in 2018. These initiatives provided a foundation upon which new rail plans will be developed. As updates to the CSRP and other rail-related developments take place, it is important for the state to acknowledge and embrace these new plans. This would mean building off the strength of existing plans and carefully considering the recommendations laid out in this section.

In the Spring of 2020, Caltrans released "Analysis of Proposed Cal-ITP Initiatives: A Feasibility Study." This study is intended to establish the foundation for the state's 2022 State Rail Plan. The Cal-ITP initiative details a strategic vision for a coordinated, integrated state rail network. The Cal-ITP initiative outlines strategies for increasing state investment, creating a framework for improved stakeholder coordination, developing new evaluation metrics, and enhancing public outreach. The initiative focuses on creating new methods and wider use of new fare payment systems. This would allow travelers to seamlessly pay for intercity, commuter rail, and transit services, and thereby promote ease of access to multiple modes. The initiative also proposes an improved intermodal scheduling paradigm called "Pulse Scheduling." Pulse scheduling is intended to improve connectivity, increase reliability, improve rail capacity, and reduce overall travel times for users of California's various mobility services.

The concepts presented in the Cal-ITP study are consistent with many of the recommendations of this paper. They are also consistent with ongoing and broad initiatives by Caltrans on integrated mobility. These would include trip planning, payment, and equity. It is recommended that the new concepts and future rail plans are evaluated to address all opportunities for enhancement. These recommendations include the creation and involvement of rail advisory bodies, and periodic review to support ongoing multi-modal initiatives by Caltrans.

\subsection{Revise FRA Guidance}

California produced a very solid rail plan that lays the groundwork for future measurable performance. It also has the potential to be highly integrated with the state's internal transportation network as well at establishing regional, national, and international multimodal transportation plans.

The FRA Guidance, last updated in 2013, should be updated to encourage all states to do more than "check the boxes." The goal of this update would also include establishing a National Rail Policy and Plan. The FRA may also follow the lead of California or implement less proscriptive review and acceptance of State Rail Plans. 


\section{Conclusion}

Through the review of the State Rail Plans currently on file with the FRA—and required for grant eligibility under Section 303 of PRIAA — it is clear that most states share common goals, including improving the safety of their transportation systems. This is especially seen in those plans highlighted in this paper (e.g., California, Colorado, Michigan, North Carolina, Virginia, and Washington). These goals also include the improvement of their transportation systems to stimulate, support, and enhance the movement of goods to ensure a prosperous economy.

Some states (such as Virginia, Colorado and California) have specific initiatives to support shortline promoting and the development their railroads. In California, CTC has already implemented a short-line railroad improvement program (SLIP) that provides a one-time appropriation to support development and improvements to short-line rail infrastructure. This initiative could serve as a model for Virginia, Colorado, and other states who are contemplating strategies for improving short-line rail service-a critical link in moving freight from distant or disparate location to the mainlines of the nation's Class I rail systems.

In most states, the intercity and commuter rail services operate on rails owned by freight rail companies. This means that passenger rail performance has both an impact on freight rail service as well as freight rail service having an impact on the reliability and performance of intercity and commuter rail service. In Virginia, California, and Michigan, for example, collaborations between the states and the freight rail companies are supporting projects to expand rail capacity and reduce the bottlenecks and scheduling problems that impede both freight and passenger rail traffic.

Other examples of state rail planning leadership include how Virginia and California are similarly exploring ways to improve rail service to their ports. Both states are major connecting points for international and transcontinental mobility and both are experiencing huge new demands on the capacity of their transportation systems. These demands can be seen in their railways and roadways.

States such as California, Washington, Virginia, and North Carolina are each exploring the development of passenger rail service within megaregions. These states are also exploring specifically designated corridors that connect multiple states and extend into Canada to the north, and Mexico to the south. With the evolution of high-speed passenger rail service, interstate and international collaborations will prove critical to the aspirations of these states and many others throughout the U.S.

Customer-facing technologies (such as mobility as a service (MaaS)) are evolving in many areas of the U.S. California and Washington have been leading the way, but there is still a considerable amount of work to be done linking various modalities— such as public transit, commuter and intercity passenger rail, ride share, and even aviation— to a uniform technology that will improve trip planning and payment. 
Caltrans, APTA, and others have undertaken significant initiatives. Collaboration between service providers offers great benefits for travelers and service operators and should be addressed in future State Rail Plans. They should also be addressed in future state transportation plans.

As noted in earlier chapters of this report, both the FRA and many states take a light touch to setting measurable goals for the performance of their rail infrastructure. However, there is only one exception in these light measures: that of on-time performance of passenger and freight rail service. This has been the subject of legislative, regulatory, and judicial deliberations. The rationale for this light touch is grounded in the fact that most of the nation's rail infrastructure is privately owned. Nonetheless, there are significant examples of states (e.g. Virginia, California, Michigan, and Wisconsin) where collaboration between the state and the private sector are producing potentially significant improvements.

However, in both the legislative mandate for state rail planning and the regulatory guidance for those plans, there are major gaps. These gaps significantly limit the value and impact of such planning efforts. For example, there are no metrics that track the progress of any states' effort from the aspirational expressions of earlier plans to the aspirational expressions of the most recent plan. There are also no metrics that set goals to be addressed in future plans. How are decision makers to know what success is or looks like? As a result of MAP-21 and the FAST Act there are means by which MPOs and states can prioritize infrastructure projects by their perceived ability to reduce congestion. However, there are no measures for addressing economic impact, improved mobility, or the sustainability of the infrastructure to name a few. Clearly, most State Plans have expressed aspirational goals regarding GHG reductions. However, it is important to note that this is not the only measure of an effective rail plan.

Another area of high priority concern is the resilience of the rail infrastructure. Recent natural disasters and the various emerging and ongoing pandemics suggest that the federal government, states, and service providers need to include future rail and state transportation plans strategies. They should also include standards and measurements to effectively address these challenges. 


\section{Appendix A: Matrix of State Rail Plans According to the FRA Requirements}




\begin{tabular}{|c|c|c|c|c|c|c|c|c|c|}
\hline State & State Rail Plan & $\begin{array}{l}\text { Executive } \\
\text { Summary }\end{array}$ & $\begin{array}{c}\text { The Role of Rail in } \\
\text { Statewide Trans- } \\
\text { portation }\end{array}$ & $\begin{array}{l}\text { State's Exist- } \\
\text { ing Rail Sys- } \\
\text { tem }\end{array}$ & $\begin{array}{l}\text { Proposed Passenger } \\
\text { Rail Improvements and } \\
\text { Investments }\end{array}$ & $\begin{array}{l}\text { Proposed Freight } \\
\text { Rail Improve- } \\
\text { ments and Invest- } \\
\text { ments }\end{array}$ & $\begin{array}{l}\text { State's Rail } \\
\text { Service and In- } \\
\text { vestment Pro- } \\
\text { gram }\end{array}$ & $\begin{array}{l}\text { Coordination } \\
\text { and Review }\end{array}$ & Technical Appendix \\
\hline Alabama & $\begin{array}{l}\text { Alabama } 2013 \\
\text { State Rail Plan }\end{array}$ & $\begin{array}{l}\text { No Executive } \\
\text { Summary }\end{array}$ & Chapter 1 & $\begin{array}{l}\text { Chapters } 2 \text {, } \\
3 \text {, and } 4\end{array}$ & Chapter 5 & Chapter 6 & Chapter 7 & Chapter 8 & $\begin{array}{c}\text { Appendix A - list of } \\
\text { stakeholders, } 29 \text { tables, } \\
24 \text { figures }\end{array}$ \\
\hline Alaska & $\begin{array}{c}\text { Alaska Rail } \\
\text { Plan Final } 2016\end{array}$ & Pages I-ix & $\begin{array}{l}\text { Chapter 1, Chapter } \\
\text { 2-History of Rail- } \\
\text { roads in Alaska }\end{array}$ & Chapter 3 & Chapter 4 & Chapter 5 & Chapter 6 & Chapter 7 & $\begin{array}{l}\text { Appendix A-E, } 29 \text { ta- } \\
\text { bles, } 49 \text { figures }\end{array}$ \\
\hline Arizona & $\begin{array}{l}\text { Arizona State } \\
\text { Rail Plan } \\
\text { March } 2011\end{array}$ & $\begin{array}{c}\text { Introduction } \\
\text { and Over- } \\
\text { view, Chapter } \\
1\end{array}$ & $\begin{array}{l}\text { Chapter } 2 \text { Arizona } \\
\text { Rail Vision, Goals } \\
\text { and Objectives }\end{array}$ & $\begin{array}{l}\text { Chapter } 3 \mathrm{Is}^{-} \\
\text {sues and Op- } \\
\text { portunities }\end{array}$ & $\begin{array}{l}\text { Chapter } 4 \text { Proposed } \\
\text { Rail Projects, Chapter } 5 \\
\text { Funding of Proposed } \\
\text { Rail Projects }\end{array}$ & $\begin{array}{c}\text { Chapter } 4 \text { Pro- } \\
\text { posed Rail Projects }\end{array}$ & $\begin{array}{l}\text { Chapter } 5 \\
\text { Funding of } \\
\text { Proposed Rail } \\
\text { Projects }\end{array}$ & $\begin{array}{l}\text { Appendix B } \\
\text { Public and } \\
\text { Stakeholder In- } \\
\text { volvement }\end{array}$ & $\begin{array}{c}\text { Appendix A through D, } \\
29 \text { Tables, } 74 \text { Figures }\end{array}$ \\
\hline Arkansas & $\begin{array}{c}2015 \text { Arkansas } \\
\text { State Rail } \\
\text { Plan-Final } \\
\text { Report }\end{array}$ & Pages 1-6 & Chapters 1, 2, 7 & Chapters 2, 3 & Chapters $3,5,10,12$ & $\begin{array}{c}\text { Chapter 2, 4, 7, 8, } \\
11\end{array}$ & $\begin{array}{c}\text { Chapters } 5.8,9, \\
\text { and } 12,\end{array}$ & Chapter 13 & 100 figures, 62 tables \\
\hline California & $\begin{array}{l}2018 \text { State Rail } \\
\text { Plan }\end{array}$ & $\begin{array}{c}\text { Executive } \\
\text { Summary and } \\
\text { overview }\end{array}$ & Section $1.1-1.8$ & $\begin{array}{l}\text { Section 2.1- } \\
\quad 2.3\end{array}$ & Section 4.1-4.10 & Section $5.1-5.3$ & Section 6.1-6.4 & $\begin{array}{l}\text { Section 7.1-7.2 } \\
\text { Public Outreach }\end{array}$ & 33 tables, 49 exhibits \\
\hline
\end{tabular}




\begin{tabular}{|c|c|c|c|c|c|c|c|c|c|}
\hline State & State Rail Plan & $\begin{array}{l}\text { Executive Sum- } \\
\text { mary }\end{array}$ & $\begin{array}{c}\text { The Role of Rail in } \\
\text { Statewide Trans- } \\
\text { portation }\end{array}$ & $\begin{array}{l}\text { State's Ex- } \\
\text { isting Rail } \\
\text { System }\end{array}$ & $\begin{array}{l}\text { Proposed Passenger } \\
\text { Rail Improvements } \\
\text { and Investments }\end{array}$ & $\begin{array}{l}\text { Proposed Freight } \\
\text { Rail Improvements } \\
\text { and Investments }\end{array}$ & $\begin{array}{l}\text { State's Rail Ser- } \\
\text { vice and Invest- } \\
\text { ment Program }\end{array}$ & $\begin{array}{l}\text { Coordina- } \\
\text { tion and } \\
\text { Review }\end{array}$ & Technical Appendix \\
\hline Colorado & $\begin{array}{l}\text { State Freight and } \\
\text { Passenger Rail } \\
\text { Plan-March } 2012\end{array}$ & $\begin{array}{l}\text { Chapter } 1 \text { Intro- } \\
\text { duction, Chapter } \\
8 \text { Plan Summary }\end{array}$ & N/A & $\begin{array}{l}\text { Chapters } 1 \text {, } \\
2 \text {, and } 3\end{array}$ & Chapters 5 and 6 & Chapters 5 and 6 & $\begin{array}{l}\text { Chapters 5,6, } \\
\text { and } 7\end{array}$ & Chapter 4 & $\begin{array}{l}\text { Appendix A-E, } 40 \text { fig- } \\
\text { ures, } 39 \text { tables, A-D }\end{array}$ \\
\hline Connecticut & $\begin{array}{l}\text { 2012-2016 Con- } \\
\text { necticut State Rail } \\
\text { Plan }\end{array}$ & $\begin{array}{c}\text { Executive Sum- } \\
\text { mary, Chapter } 1 \\
\text { Vision, Goals, } \\
\text { Etc. }\end{array}$ & Chapters 3-7 & $\begin{array}{c}\text { Chapters 3- } \\
7\end{array}$ & Chapters 11,12 & $\begin{array}{l}\text { Chapters } 6,7,11, \\
12\end{array}$ & $\begin{array}{c}\text { Chapters } 8,11, \\
12\end{array}$ & Chapter 14 & $\begin{array}{c}\text { Appendix A-C, } 58 \text { Fig- } \\
\text { ures }\end{array}$ \\
\hline Delaware & $\begin{array}{c}\text { Delaware State Rail } \\
\text { Plan Final } 2011\end{array}$ & $\begin{array}{l}\text { Chapter } 2 \text { Intro- } \\
\text { duction-Purpose } \\
\text { of the Plan }\end{array}$ & Chapters $1,3,4,5$ & $\begin{array}{l}\text { Chapters 4, } \\
5\end{array}$ & Chapters 3,9 & Chapters 4, 5, 9 & Chapters 8,9 & Chapter 2 & 12 Tables, 29 Figures \\
\hline $\begin{array}{l}\text { District of Colum- } \\
\text { bia }\end{array}$ & $\begin{array}{l}\text { State Rail Plan: Fi- } \\
\text { nal Report } 2017\end{array}$ & N/A & Chapter 1 & Chapter 3 & Chapter 4 & Chapter 5 & Chapter 6 & Chapter 2 & $\begin{array}{l}\text { Appendix A-J, } 32 \text { Ta- } \\
\text { bles, } 71 \text { Figures }\end{array}$ \\
\hline Florida & $\begin{array}{l}\text { Rail System Plan } \\
2018 \text { Update }\end{array}$ & Pages viii-xii & Chapter 1 & Chapter 2 & Chapter 3 & Chapter 4 & Chapter 5 & Chapter 6 & $\begin{array}{l}\text { Appendix A-I, } 49 \mathrm{Ta}^{-} \\
\text {bles, } 32 \text { Figures }\end{array}$ \\
\hline
\end{tabular}




\begin{tabular}{|c|c|c|c|c|c|c|c|c|c|}
\hline State & State Rail Plan & $\begin{array}{l}\text { Executive } \\
\text { Summary }\end{array}$ & $\begin{array}{c}\text { The Role of Rail in } \\
\text { Statewide Transpor- } \\
\text { tation }\end{array}$ & $\begin{array}{l}\text { State's Exist- } \\
\text { ing Rail Sys- } \\
\text { tem }\end{array}$ & $\begin{array}{l}\text { Proposed Passenger } \\
\text { Rail Improvements } \\
\text { and Investments }\end{array}$ & $\begin{array}{l}\text { Proposed Freight Rail } \\
\text { Improvements and } \\
\text { Investments }\end{array}$ & $\begin{array}{l}\text { State's Rail Ser- } \\
\text { vice and Invest- } \\
\text { ment Program }\end{array}$ & $\begin{array}{l}\text { Coordina- } \\
\text { tion and Re- } \\
\quad \text { view }\end{array}$ & Technical Appendix \\
\hline Georgia & $\begin{array}{c}2015 \text { Georgia State } \\
\text { Rail Plan }\end{array}$ & Pages I-ix & Chapter 1 & Chapter 2 & Chapter 3 & Chapter 4 & Chapter 5 & Chapter 6 & $\begin{array}{l}\text { Appendix A-F, } 54 \mathrm{Ta}^{-} \\
\text {bles, } 43 \text { Figures }\end{array}$ \\
\hline Idaho & $\begin{array}{l}\text { Idaho Statewide } \\
\text { Rail Plan } 2013\end{array}$ & $\begin{array}{l}\text { Pages } \\
\text { ES-1- } \\
\text { ES-6 }\end{array}$ & Section 1 & $\begin{array}{c}\text { Sections } 2,3 \text {, } \\
\text { and } 4\end{array}$ & Section 5 & Section 5 & Section 6 & $\begin{array}{l}\text { Section 7- } \\
\text { Appendix A } \\
\text { and B }\end{array}$ & Appendix A and B \\
\hline Illinois & $\begin{array}{l}2017 \text { Illinois State } \\
\text { Rail Plan Update }\end{array}$ & $\begin{array}{l}\text { Pages 13- } \\
25\end{array}$ & Chapter 1 & Chapter 2 & Chapter 3 & Chapter 4 & Chapter 5 & Chapter 6 & $\begin{array}{c}\text { Appendix Pages 275- } \\
\text { 276, } 36 \text { Tables, } 138 \text { Fig- } \\
\text { ures }\end{array}$ \\
\hline Indiana & $\begin{array}{c}\text { Indiana State Rail } \\
\text { Plan October } 2017\end{array}$ & $\begin{array}{c}\text { Pages S- } \\
1-\mathrm{S}-12\end{array}$ & Chapter 1 & Chapter 2 & Chapter 3 & Chapter 4 & Chapter 5 & Chapter 6 & $\begin{array}{l}\text { Appendix A-D, } 39 \text { Ta- } \\
\text { bles, } 55 \text { Figures }\end{array}$ \\
\hline Iowa & $\begin{array}{c}\text { Iowa State Rail } \\
\text { Plan Final-Febru- } \\
\text { ary } 2017\end{array}$ & Pages 1-6 & Chapter 1 & Chapter 2 & Chapter 3 & Chapter 4 & Chapter 5 & Chapter 6 & Appendix A -F \\
\hline
\end{tabular}




\begin{tabular}{|c|c|c|c|c|c|c|c|c|c|}
\hline State & State Rail Plan & $\begin{array}{l}\text { Executive } \\
\text { Summary }\end{array}$ & $\begin{array}{c}\text { The Role of Rail in } \\
\text { Statewide Transpor- } \\
\text { tation }\end{array}$ & $\begin{array}{l}\text { State's Ex- } \\
\text { isting Rail } \\
\text { System }\end{array}$ & $\begin{array}{l}\text { Proposed Passenger } \\
\text { Rail Improvements } \\
\text { and Investments }\end{array}$ & $\begin{array}{l}\text { Proposed Freight } \\
\text { Rail Improvements } \\
\text { and Investments }\end{array}$ & $\begin{array}{l}\text { State's Rail Ser- } \\
\text { vice and Invest- } \\
\text { ment Program }\end{array}$ & $\begin{array}{l}\text { Coordina- } \\
\text { tion and } \\
\text { Review }\end{array}$ & Technical Appendix \\
\hline Kansas & $\begin{array}{c}\text { Kansas Statewide } \\
\text { Rail Plan-Septem- } \\
\text { ber } 2017\end{array}$ & $\begin{array}{l}\text { No Execu- } \\
\text { tive Sum- } \\
\text { mary }\end{array}$ & Chapter 1 & Chapter 2 & Chapter 3 & Chapter 4 & Chapter 5 & Chapter 6 & 38 Figures, 31 Tables \\
\hline Kentucky & $\begin{array}{c}2015 \text { Kentucky } \\
\text { Statewide Rail Plan }\end{array}$ & $\begin{array}{l}\text { ES-1-ES- } \\
9\end{array}$ & $\begin{array}{l}\text { Chapter 1, Intro- } \\
\text { duction }\end{array}$ & $\begin{array}{c}\text { Chapters 2, } \\
3\end{array}$ & Chapter 3 & Chapter 2 & Chapter 4 & Chapter 7 & $\begin{array}{c}\text { Chapters 5, 6, 8, Ap- } \\
\text { pendix A-B, } 31 \text { Figures, } \\
24 \text { Tables }\end{array}$ \\
\hline Louisiana & $\begin{array}{l}\text { Louisiana State Rail } \\
\text { Plan June } 2015\end{array}$ & Pages 1-7 & Chapter 1 & Chapter 2 & Chapter 3 & Chapter 4 & Chapter 5 & Chapter 6 & $\begin{array}{l}\text { Appendix A-J, } 49 \mathrm{Ta}^{-} \\
\text {bles, } 25 \text { Figures }\end{array}$ \\
\hline Maine & $\begin{array}{l}2014 \text { Maine State } \\
\text { Rail Plan }\end{array}$ & $\begin{array}{l}\text { No Execu- } \\
\text { tive Sum- } \\
\quad \text { mary }\end{array}$ & Chapters 2, 3, 4 & $\begin{array}{c}\text { Chapters 2, } \\
3\end{array}$ & Chapter 3 & Chapters 2, 4, 6 & Chapters 7, 8 & Chapter 1 & $\begin{array}{c}\text { Appendix A-M, } 93 \text { Fig- } \\
\text { ures }\end{array}$ \\
\hline Maryland & $\begin{array}{l}\text { Maryland Statewide } \\
\text { Rail Plan } 2015\end{array}$ & $\begin{array}{c}\text { Chapters } 1, \\
3\end{array}$ & Chapters 4,5 & $\begin{array}{c}\text { Chapters } 5 \text {, } \\
6\end{array}$ & Chapters 5,6 & Chapters 5, 6 & Chapter 6 & $\begin{array}{c}\text { Chapters 1, } \\
8\end{array}$ & $\begin{array}{c}\text { Chapters 7, 8, 9, } 10 \mathrm{Ta} \text { - } \\
\text { bles, } 20 \text { Figures }\end{array}$ \\
\hline
\end{tabular}




\begin{tabular}{|c|c|c|c|c|c|c|c|c|c|}
\hline State & State Rail Plan & $\begin{array}{l}\text { Executive } \\
\text { Summary }\end{array}$ & $\begin{array}{c}\text { The Role of Rail in } \\
\text { Statewide Transpor- } \\
\text { tation }\end{array}$ & $\begin{array}{l}\text { State's Exist- } \\
\text { ing Rail Sys- } \\
\text { tem }\end{array}$ & $\begin{array}{l}\text { Proposed Passenger } \\
\text { Rail Improvements } \\
\text { and Investments }\end{array}$ & $\begin{array}{l}\text { Proposed Freight Rail } \\
\text { Improvements and } \\
\text { Investments }\end{array}$ & $\begin{array}{l}\text { State's Rail Ser- } \\
\text { vice and Invest- } \\
\text { ment Program }\end{array}$ & $\begin{array}{l}\text { Coordina- } \\
\text { tion and } \\
\text { Review }\end{array}$ & Technical Appendix \\
\hline Massachusetts & $\begin{array}{c}\text { Massachusetts } \\
\text { State Rail Plan } \\
\text { May } 2018\end{array}$ & $\begin{array}{c}\text { Pages } 1- \\
14\end{array}$ & Chapter 1 & Chapter 2 & Chapter 3 & Chapter 4 & Chapter 5 & Chapter 6 & Appendix A \& B \\
\hline Michigan & $\begin{array}{c}\text { Michigan State } \\
\text { Rail Plan Final Re- } \\
\text { port }\end{array}$ & $\begin{array}{l}\text { No execu- } \\
\text { tive sum- } \\
\text { mary }\end{array}$ & Chapter 1 & Chapter 2 & Chapters 3,7 & Chapters 3, 7 & Chapters 3,7 & $\begin{array}{c}\text { Chapters 5, } \\
6\end{array}$ & 30 Tables, 12 Figures \\
\hline Minnesota & $\begin{array}{c}\text { Minnesota State } \\
\text { Rail Plan Draft } \\
\text { March } 2015\end{array}$ & $\begin{array}{l}\text { Pages vii- } \\
\quad \text { xxi }\end{array}$ & Chapter 1 & Chapter 2 & Chapter 3 & Chapter 4 & Chapter 5 & Chapter 6 & $\begin{array}{l}\text { Appendix A-G, } 24 \text { Ta- } \\
\text { bles, } 28 \text { Figures }\end{array}$ \\
\hline Mississippi & $\begin{array}{l}\text { Mississippi State } \\
\text { Rail Plan Update } \\
\text { March } 2016\end{array}$ & $\begin{array}{c}\text { ES-1-ES- } \\
9\end{array}$ & Chapter 1 & Chapter 2 & Chapter 3 & Chapter 4 & Chapter 5 & Chapter 6 & $\begin{array}{c}\text { Appendix A-C, } 18 \text { Fig- } \\
\text { ures, } 20 \text { Tables }\end{array}$ \\
\hline Missouri & $\begin{array}{l}\text { Missouri State Rail } \\
\text { Plan May } 2012\end{array}$ & $\begin{array}{l}\text { No execu- } \\
\text { tive sum- } \\
\text { mary }\end{array}$ & Chapter 1 & $\begin{array}{c}\text { Chapters } 2, \\
3,4,5\end{array}$ & Chapter 6 & Chapters 2, 5 & Chapter 8 & $\begin{array}{l}\text { Chapters } 7 \\
\quad 9,10\end{array}$ & 24 Tables, 13 Figures \\
\hline
\end{tabular}




\begin{tabular}{|c|c|c|c|c|c|c|c|c|c|}
\hline State & State Rail Plan & Executive Summary & $\begin{array}{c}\text { The Role of Rail } \\
\text { in Statewide } \\
\text { Transportation }\end{array}$ & $\begin{array}{l}\text { State's Ex- } \\
\text { isting Rail } \\
\text { System }\end{array}$ & $\begin{array}{l}\text { Proposed Passen- } \\
\text { ger Rail Improve- } \\
\text { ments and Invest- } \\
\quad \text { ments }\end{array}$ & $\begin{array}{l}\text { Proposed Freight } \\
\text { Rail Improvements } \\
\text { and Investments }\end{array}$ & $\begin{array}{c}\text { State's Rail Ser- } \\
\text { vice and Invest- } \\
\text { ment Program }\end{array}$ & $\begin{array}{l}\text { Coordina- } \\
\text { tion and } \\
\text { Review }\end{array}$ & Technical Appendix \\
\hline Montana & $\begin{array}{l}2010 \text { Montana } \\
\text { State Rail Plan- } \\
\text { Final Report }\end{array}$ & ES-1-ES-15 & Chapter 1 & $\begin{array}{c}\text { Chapters } \\
2,3,5,7\end{array}$ & Chapter 4 & Chapters 2, 5, 7 & Chapter 6 & Chapter 7 & 39 Tables, 115 Figures \\
\hline Nebraska & $\begin{array}{l}\text { Nebraska Railway } \\
\text { Council Study } \\
\text { December } 2003\end{array}$ & $\begin{array}{c}\text { Not a state rail plan- } \\
\text { does not conform to } \\
\text { FRA state rail plan } \\
\text { guidance }\end{array}$ & N/A & N/A & N/A & N/A & N/A & N/A & N/A \\
\hline Nevada & $\begin{array}{l}\text { Nevada State Rail } \\
\quad \text { Plan } 2012\end{array}$ & Summary pages I-v & Chapter 1 & Chapter 2 & Chapter 3 & Chapter 4 & Chapter 5 & Chapter 6 & $\begin{array}{c}\text { Appendix A-J, } 36 \mathrm{Ta}^{-}- \\
\text {bles, } 45 \text { Figures, } 5 \mathrm{Ex}- \\
\text { hibits }\end{array}$ \\
\hline New Hampshire & $\begin{array}{c}2012 \text { New Hamp- } \\
\text { shire State Rail } \\
\text { Plan }\end{array}$ & Chapter 1: Pages 1-8 & Chapter 2 & $\begin{array}{c}\text { Chapters 2, } \\
4,5\end{array}$ & Chapters $5,6,7,8$ & $\begin{array}{c}\text { Chapters } 3.4,5,6 \\
7,8\end{array}$ & Chapters 7, 8 & $\begin{array}{l}\text { Introduc- } \\
\text { tion and } \\
\text { Chapter } 9\end{array}$ & 37 Tables, 49 Figures \\
\hline New Jersey & $\begin{array}{l}\text { New Jersey State } \\
\text { Rail Plan Final } \\
\text { Report April } 2015\end{array}$ & ES-1-11 & Chapter 1 & $\begin{array}{l}\text { Chapter 2, } \\
\quad 4,5\end{array}$ & Chapter 3 & Chapter 2 & Chapter 5 & $\begin{array}{c}\text { Forward, } \\
\text { page iii }\end{array}$ & 61 Figures, 63 Tables \\
\hline
\end{tabular}




\begin{tabular}{|c|c|c|c|c|c|c|c|c|c|}
\hline State & State Rail Plan & $\begin{array}{l}\text { Executive } \\
\text { Summary }\end{array}$ & $\begin{array}{c}\text { The Role of Rail in } \\
\text { Statewide Trans- } \\
\text { portation }\end{array}$ & $\begin{array}{l}\text { State's Ex- } \\
\text { isting Rail } \\
\text { System }\end{array}$ & $\begin{array}{l}\text { Proposed Passenger } \\
\text { Rail Improvements } \\
\text { and Investments }\end{array}$ & $\begin{array}{l}\text { Proposed Freight } \\
\text { Rail Improvements } \\
\text { and Investments }\end{array}$ & $\begin{array}{l}\text { State's Rail Ser- } \\
\text { vice and Invest- } \\
\text { ment Program }\end{array}$ & $\begin{array}{l}\text { Coordina- } \\
\text { tion and } \\
\text { Review }\end{array}$ & Technical Appendix \\
\hline New Mexico & $\begin{array}{c}\text { New Mexico State } \\
\text { Rail Plan March 27, } \\
2014\end{array}$ & $\begin{array}{c}\text { ES-1-ES- } \\
9\end{array}$ & Chapters 1,3 & Chapter 2 & Chapter 4 & Chapter 4 & Chapter 5, 6 & Chapter 1 & $\begin{array}{c}\text { Appendix A-C, } 42 \mathrm{Ta}- \\
\text { bles, } 59 \text { Figures }\end{array}$ \\
\hline New York & $\begin{array}{c}2009 \text { New York State } \\
\text { Rail Plan }\end{array}$ & Pages $v-\mathrm{x}$ & Chapters 1,2 & Chapter 3 & Chapters 5,6 & Chapter 4 & Chapters 11,12 & Chapter 10 & $\begin{array}{c}\text { Appendix A \& B, } 71 \\
\text { Figures }\end{array}$ \\
\hline North Carolina & $\begin{array}{c}\text { Comprehensive State } \\
\text { Rail Plan, August } \\
2015\end{array}$ & $\begin{array}{l}\text { Introduc- } \\
\text { tion, Pages } \\
\text { I-iii }\end{array}$ & Chapter 1 & Chapter 2 & Chapter 3 & Chapter 4 & Chapter 5 & Chapter 6 & $\begin{array}{c}\text { Appendix A-H, } 127 \\
\text { Figures, } 61 \text { Tables }\end{array}$ \\
\hline North Dakota & $\begin{array}{c}2040 \text { North Dakota } \\
\text { State Rail Plan No- } \\
\text { vember } 2017\end{array}$ & $\begin{array}{c}\text { No Execu- } \\
\text { tive Sum- } \\
\text { mary }\end{array}$ & Chapter 1 & Chapter 2 & Chapter 3 & Chapter 4 & Chapter 5 & Chapter 6 & $\begin{array}{c}\text { Appendix A-B, } 61 \mathrm{Ta}- \\
\text { bles, } 85 \text { Figures }\end{array}$ \\
\hline Ohio & $\begin{array}{c}\text { Ohio Statewide Rail } \\
\text { Plan Final Report } \\
5 / 10 / 2010\end{array}$ & $\begin{array}{l}\text { Chapter } 1 \text {, } \\
\text { Introduc- } \\
\text { tion }\end{array}$ & Chapter 2 & Chapter 2 & Chapters 9, 10 & $\begin{array}{c}\text { Chapters } 3,4,5,6,7 \\
8\end{array}$ & $\begin{array}{c}\text { Chapters } 11,12 \\
\text { Appendix C and } \\
\text { D }\end{array}$ & Appendix A & $\begin{array}{l}\text { Appendix A-D, } 74 \text { Ex- } \\
\text { hibits }\end{array}$ \\
\hline
\end{tabular}




\begin{tabular}{|c|c|c|c|c|c|c|c|c|c|}
\hline State & State Rail Plan & $\begin{array}{l}\text { Executive } \\
\text { Summary }\end{array}$ & $\begin{array}{c}\text { The Role of Rail in } \\
\text { Statewide Trans- } \\
\text { portation }\end{array}$ & $\begin{array}{l}\text { State's Exist- } \\
\text { ing Rail Sys- } \\
\text { tem }\end{array}$ & $\begin{array}{l}\text { Proposed Passenger } \\
\text { Rail Improvements } \\
\text { and Investments }\end{array}$ & $\begin{array}{l}\text { Proposed Freight } \\
\text { Rail Improvements } \\
\text { and Investments }\end{array}$ & $\begin{array}{l}\text { State's Rail Ser- } \\
\text { vice and Invest- } \\
\text { ment Program }\end{array}$ & $\begin{array}{l}\text { Coordina- } \\
\text { tion and } \\
\text { Review }\end{array}$ & Technical Appendix \\
\hline Oklahoma & $\begin{array}{l}\text { Oklahoma State } \\
\text { Rail Plan } 2018\end{array}$ & Pages 1-13 & Chapter 1 & Chapter 2 & Chapter 3 & Chapter 4 & Chapter 5 & Chapter 6 & $\begin{array}{l}\text { Appendix A-F, } 46 \text { Ta- } \\
\text { bles, } 50 \text { Figures }\end{array}$ \\
\hline Oregon & $\begin{array}{l}\text { Oregon State Rail } \\
\text { Plan September 18, } \\
2014\end{array}$ & Pages 1-15 & Chapter 1 & $\begin{array}{l}\text { Chapters 2, } \\
3\end{array}$ & Chapters 2, 3 & Chapters 2, 3 & Chapter 4 & Chapter 5 & $\begin{array}{l}\text { Appendix A-D, } 16 \text { Ta- } \\
\text { bles, } 20 \text { Figures }\end{array}$ \\
\hline Pennsylvania & $\begin{array}{l}2015 \text { Pennsylvania } \\
\text { State Rail Plan, De- } \\
\text { cember } 2016\end{array}$ & $\begin{array}{l}\text { No Execu- } \\
\text { tive Sum- } \\
\text { mary }\end{array}$ & Chapter 1 & Chapter 2 & Chapter 3 & Chapter 4 & Chapter 5 & Chapter 6 & $\begin{array}{c}\text { Appendix A-M, } 86 \text { Fig- } \\
\text { ures, } 164 \text { Tables }\end{array}$ \\
\hline Rhode Island & $\begin{array}{l}\text { Rhode Island Rail } \\
\text { Plan } 2014\end{array}$ & $\begin{array}{l}\text { No Execu- } \\
\text { tive Sum- } \\
\quad \text { mary }\end{array}$ & Chapter 1 & $\begin{array}{l}\text { Chapter 3, 7, } \\
\text { 8, Appendix } \\
\text { A }\end{array}$ & $5,6,9$ & Chapter 4 & Chapters 3, 6, 9 & $\begin{array}{l}\text { Chapters 2, } \\
\text { 9, Appendix } \\
\text { B }\end{array}$ & $\begin{array}{l}\text { Appendix A \& B, } 30 \\
\text { Figures, } 17 \text { Tables }\end{array}$ \\
\hline South Carolina & $\begin{array}{l}\text { Charting a Course } \\
\text { to } 2040 \text {-December } \\
2014\end{array}$ & $\begin{array}{c}\text { Executive } \\
\text { Summary } \\
1-11\end{array}$ & Chapter 1 & Chapter 2 & Chapter 3 & Chapter 4 & Chapter 5 & Chapter 6 & $\begin{array}{l}\text { Appendix A \& B, } 50 \\
\text { Tables, } 30 \text { Figures }\end{array}$ \\
\hline
\end{tabular}




\begin{tabular}{|c|c|c|c|c|c|c|c|c|c|}
\hline State & State Rail Plan & $\begin{array}{l}\text { Executive } \\
\text { Summary }\end{array}$ & $\begin{array}{c}\text { The Role of Rail in } \\
\text { Statewide Transpor- } \\
\text { tation }\end{array}$ & $\begin{array}{l}\text { State's Ex- } \\
\text { isting Rail } \\
\text { System }\end{array}$ & $\begin{array}{c}\text { Proposed Passenger } \\
\text { Rail Improvements } \\
\text { and Investments }\end{array}$ & $\begin{array}{l}\text { Proposed Freight } \\
\text { Rail Improvements } \\
\text { and Investments }\end{array}$ & $\begin{array}{c}\text { State's Rail Ser- } \\
\text { vice and Invest- } \\
\text { ment Program }\end{array}$ & $\begin{array}{l}\text { Coordina- } \\
\text { tion and } \\
\text { Review }\end{array}$ & Technical Appendix \\
\hline South Dakota & $\begin{array}{l}\text { South Dakota State } \\
\text { Rail Plan - } 2014\end{array}$ & Volume 1 & $\begin{array}{c}\text { Chapter 1, Volume } \\
2\end{array}$ & Volume 2 & $\begin{array}{l}\text { No passenger rail } \\
\text { component }\end{array}$ & Volume 2, Chapter 5 & $\begin{array}{c}\text { Chapters 6, 7, } \\
\text { Volume } 2\end{array}$ & $\begin{array}{l}\text { Chapter } 8 \\
\text { Volume } 2\end{array}$ & $\begin{array}{l}\text { Volume 1: Appendix A } \\
\& \text { B, Volume 2: Appen- } \\
\text { dix A-C }\end{array}$ \\
\hline Tennessee & $\begin{array}{c}\text { Tennessee } \\
\text { Statewide Rail Plan } \\
\text { Update } 2019\end{array}$ & $\begin{array}{l}\text { No Execu- } \\
\text { tive Sum- } \\
\text { mary }\end{array}$ & Sections 1,2 & $\begin{array}{l}\text { Sections } 3 \\
4,7,8\end{array}$ & Section 10 & Section 9 & Section 11 & Section 12 & \\
\hline Texas & $\begin{array}{c}2019 \text { Texas Rail } \\
\text { Plan Draft October } \\
2019\end{array}$ & $\begin{array}{l}\text { No Execu- } \\
\text { tive Sum- } \\
\text { mary }\end{array}$ & Chapter 1 & Chapter 2 & Chapter 3 & Chapter 4 & Chapter 5 & Chapter 6 & Appendix A-E \\
\hline Utah & $\begin{array}{l}\text { Utah State Rail } \\
\text { Plan, April } 2015\end{array}$ & Pages 1-10 & Chapter 1 & $\begin{array}{c}\text { Chapters } 2, \\
\quad 3,4\end{array}$ & Chapter 5 & Chapter 6 & Chapter 7 & Chapter 8 & $\begin{array}{l}9 \text { Appendices-174- } \\
\text { 202, } 62 \text { Figures, } 50 \mathrm{Ta}- \\
\text { bles }\end{array}$ \\
\hline Vermont & $\begin{array}{l}\text { Vermont State Rail } \\
\text { Plan } 2015\end{array}$ & ES-1-XV & Chapter 1 & Chapter 2 & Chapter 3 & Chapter 4 & Chapter 5 & Chapter 6 & 125 Exhibits \\
\hline
\end{tabular}




\begin{tabular}{|c|c|c|c|c|c|c|c|c|c|}
\hline State & State Rail Plan & $\begin{array}{l}\text { Executive } \\
\text { Summary }\end{array}$ & $\begin{array}{c}\text { The Role of Rail in } \\
\text { Statewide Trans- } \\
\text { portation }\end{array}$ & $\begin{array}{l}\text { State's Ex- } \\
\text { isting Rail } \\
\text { System }\end{array}$ & $\begin{array}{l}\text { Proposed Passen- } \\
\text { ger Rail Improve- } \\
\text { ments and Invest- } \\
\quad \text { ments }\end{array}$ & $\begin{array}{l}\text { Proposed Freight } \\
\text { Rail Improvements } \\
\text { and Investments }\end{array}$ & $\begin{array}{l}\text { State's Rail Ser- } \\
\text { vice and Invest- } \\
\text { ment Program }\end{array}$ & $\begin{array}{l}\text { Coordina- } \\
\text { tion and } \\
\text { Review }\end{array}$ & Technical Appendix \\
\hline Virginia & 2017 Virginia State Rail Plan & $\begin{array}{l}\text { Executive } \\
\text { Summary }\end{array}$ & Chapter 1 & Chapter 2 & Chapter 3 & Chapter 4 & Chapter 5 & Chapter 6 & Appendix A-T \\
\hline Washington & $\begin{array}{l}\text { Washington State Rail Plan } \\
\text { 2019/2040-Public Review } \\
\text { Draft—December } 2019\end{array}$ & $\begin{array}{l}\text { Introduc- } \\
\text { tion Chap- } \\
\quad \text { ter } 1\end{array}$ & Chapter 2 & $\begin{array}{c}\text { Chapters 5, } \\
6\end{array}$ & Chapter 4 & Chapter 3 & Chapters 7,8 & Chapter 9 & $\begin{array}{c}\text { Appendix A-D, } 52 \mathrm{Ex}- \\
\text { hibits }\end{array}$ \\
\hline Wyoming & $\begin{array}{l}\text { Wyoming Statewide Rail } \\
\text { Plan-March } 2015\end{array}$ & $\begin{array}{c}\text { ES-1-ES- } \\
4\end{array}$ & Chapter 1 & Chapter 2 & Chapter 3 & Chapter 4 & Chapter 5 & Chapter 6 & $\begin{array}{c}\text { Appendix A \& B, } 44 \\
\text { Tables, } 32 \text { Figures }\end{array}$ \\
\hline West Virginia & $\begin{array}{l}\text { West Virginia State Rail- } \\
\text { Plan Final December } 2013\end{array}$ & $\begin{array}{c}\text { ES-2-ES- } \\
13\end{array}$ & Chapter 1 & Chapter 2 & Chapter 3 & Chapter 4 & Chapter 5 & Chapter 6 & $\begin{array}{c}\text { Appendix 1-3, } 16 \text { Fig- } \\
\text { ures, } 30 \text { Tables }\end{array}$ \\
\hline Wisconsin & $\begin{array}{l}\text { Wisconsin Rail Plan 2030- } \\
\text { Final March 19, } 2014\end{array}$ & $\begin{array}{l}\text { Summary } \\
\text { and Chap- } \\
\quad \text { ter } 1\end{array}$ & Chapter 1 & Chapter 3 & Chapters 6, 7 & Chapter 5 & Chapter 10 & $\begin{array}{c}\text { Chapters 2, } \\
8,11,12\end{array}$ & 13 Appendices \\
\hline
\end{tabular}




\section{Abbreviations and Acronyms}

\begin{tabular}{ll}
\hline Maas & Mobility as a Service \\
FRA & Federal Railroad Administration \\
USDOT & United States Department of Transportation \\
CSRP & California State Rail Plan \\
CADOT & California Department of Transportation \\
RDD & Random Digit Dialing \\
PRIIA & Passenger Rail Investment and Improvement Act \\
FHWA & Federal Highway Administration \\
HSIPR & High-Speed Intercity Passenger Rail Program \\
FTA & Federal Transit Administration \\
AASHTO & American Association of State Highway and Transportation Officials \\
SCORT & Standing Committee on Rail Transportation \\
LSRA & Local Rail Service Assistance \\
CSFPRP & Colorado State Freight and Passenger Rail Plan \\
CDOT & Colorado Department of Transportation \\
MSRP & Michigan State Rail Plan \\
MDOT & Michigan Department of Transportation \\
ARRA & American Recovery and Reinvestment Act \\
TIGER & Transportation Investment Generating Economic Recovery \\
MITP & Michigan Transportation Plan \\
\hline
\end{tabular}


NCDOT North Carolina Department of Transportation

SRPAA State Rail Plan Approval Authority

SRTA State Rail Transportation Authority

STRACNET Strategic Rail Corridor Network

VSRP Virginia State Rail Plan

VDRP Virginia Department of Rail and Public Transportation

WSRP Washington State Rail Plan

WSDOT Washington State Department of Transportation

BNSF Burlington Northern Santa Fe Railway

UPRR Union Pacific Railroad

MAP-21 Moving Ahead for Progress in the $21^{\text {st }}$ Century Act

FAST Fixing America's Surface Transportation Act

RTP Regional Transportation Plan

CTC California Transportation Commission 


\section{Bibliography}

American Association of State Highway and Transportation Officials. (2009). State Rail Planning Best Practices: A Detailed Review of All Existing Statewide Rail Plans.

American Association of State Highway and Transportation Officials. (2016). State Rail Planning Best Practices: A Detailed Review of All Existing Statewide Rail Plans Volume 2.

Atkins, ?? (2012). NCDOT From Policy to Projects 2040 Plan. North Carolina Statewide Transportation Plan.

Benjamin R. Sperry, Tyler Collins. (2018). Improving Intercity Passenger Rail Planning Using Evidence from Passenger Survey Data. First Published August 29, 2018.

Bucklew, K. (2007). The Heartland Fast-Freight Rail System. Transportation Journal, 46(4), 3641.

California Department of Transportation. (2016). California Transportation Plan 2040.

California Department of Transportation. (2018). California State Rail Plan, Executive Summary.

California Department of Transportation. (2018). California State Rail Plan.

Chaudhury, P. D. (2003). Rail and Road in Intercity Transport: Energy and Environmental Impact. Economic and Political Weekly, 38(42), 4423-4425.

Colorado Department of Transportation (CDOT). (2015). Transportation Matters. Statewide Transportation Plan 2040.

Colorado Department of Transportation. (2012). Colorado State Freight and Passenger Rail Plan, 2012.

Cummings, J., Tumlin, J., Shao, C., Halsted, A., Mezey, P., Gillett, G., Terplan, E. (2008). (Rep.). SPUR (San Francisco Bay Area Planning and Urban Research Association). doi:10.2307/resrep22912

District of Colombia Department of Transportation. (2019). Annual Meeting. 10-31, 2019. Presentation [Webinar].

Dyer, W. \& Leitelt, L. (28 Jan 2020). Planning Staff, Washington, District of Colombia. Personal Interview [Phone Interview]. 
Haywood, R. (2001). Rail-Freight Growth and the Land Use Planning System. The Town Planning Review, 72(4), 445-467.

Houston, D., Boarnet, M., Ferguson, G., \& Spears, S. (2015). Can Compact Rail Transit Corridors Transform the Automobile City? Planning for More Sustainable Travel in Los Angeles. Urban Studies, 52(5), 938-959.

Joseph P. Schwieterman and Justin Scheidt. (1995). Survey of Current High-Speed Rail Planning Efforts in the United States.

Mathur, S., \& Srinivasan, S. (2009). High-Speed Rail in the Midwest United States: Potential for Success. Theoretical and Empirical Researches in Urban Management, 4(4 (13)), 59-74.

Mees, P. (2010). Planning for Major Rail Projects: The Melbourne Metro and Regional Rail Link.

Meyer, M. D. (2016). Transportation Planning Handbook by ITE (Institute of Transportation Engineers).

Michael Greenberg, M., Lioy, P., Ozbas, B., Mantell, N., Isukapalli, S., Lahr, M., Altiok, T., Bober, J., Lacy, C., Lowrie, K., Mayer, H., \&Rovito, J. (2013).Passenger Rail Security, Planning, and Resilience: Application of Network, Plume, and Economic Simulation Models as Decision Support Tools.

Michigan Department of Transportation (MDOT). (2016). Moving Michigan Forward. 2040 State Long-Range Transportation Plan.

Michigan Department of Transportation. (2011). Michigan State Rail Plan.

Michigan Department of Transportation. (2012). MI Transportation Plan, Moving Michigan Forward, 2035 State Long-Range Transportation Plan.

Michigan Department of Transportation. (2019). MiScorecard Performance Summary.

Mitra, S., \& Bezbaruah, A. (2014). Railroad Impacts on Wetland Habitat: GIS and Modeling Approach. Journal of Transport and Land Use, 7(1), 15-28. www.jstor.org/stable/26202669.

Nicolaisen, M. S., Olesen, M., \& Olesen, K. (2017). Vision vs. Evaluation - Case Studies of Light Rail Planning in Denmark.

Niedzielski, M., \& Malecki, E. (2012). Making Tracks: Rail Networks in World Cities. Annals of the Association of American Geographers, 102(6), 1409-1431. 
North Carolina Department of Transportation Rail Division. (2015). Comprehensive State Rail Plan.

Ross, C. (2011). Transport and Megaregions: High-Speed Rail in the United States. The Town Planning Review, 82(3), 341-348.

Rutzen, B., Hutson, N., \& Loftus-Otway, L. (2018). Mexico City, Mexico, Commuter Rail: Planning and Implementation of Multijurisdictional, Public-Private Partnership Project.

Shepherd, R. K., \& Pryke, S. D. (2014). Regional Rail Planning; A Study of the Importance of 'Steering' and 'Pragmatism' in Stakeholder Networks. European Management Journal, 32(4), 616624.

Todorovich, P. (2011). Megaregion Planning and High-Speed Rail. In Montgomery, C., Regional Planning for a Sustainable America: How Creative Programs Are Promoting Prosperity and Saving the Environment (pp. 261-267). New Brunswick, New Jersey; London: Rutgers University Press. doi:10.2307/j.ctt5hj9n5.29.

Tumlin, J. (2012). Sustainable Transportation Planning. New Jersey: Wiley Books.

United States Congress. (16 Oct 2008). 110th. Rail Safety Improvement Act. Public Law 110-432.

United States Senate. Congress Approves the Federal-Aid Highway Act-June 26, 1956. Art \& History, https://www.senate.gov/artandhistory/history/minute/Federal_Highway_Act.htm

US Army Transportation Engineering Agency. Railroads for National Defense. Accessed June 2021. https://www.sddc.army.mil/sites/TEA/Functions/SpecialAssistant/Pages/RailroadsNatio nalDefense.aspx

Verma, M., Verter, V., \& Gendreau, M. (2011). A Tactical Planning Model for Railroad Transportation of Dangerous Goods. Transportation Science, 45(2), 163-174. from www.jstor.org/stable/23017698.

Virginia Department of Rail and Public Transportation. (2017). Virginia State Rail Plan Executive Summary.

Virginia Department of Transportation. (2017a). VTRANS 2040 Vision plan.

Virginia Department of Transportation. (2017b). VTRANS 2040 Needs Assessment.

Virginia Department of Transportation. (2017c). VTRANS 2040 Freight Plan. 
Washington State Department of Transportation (2018). Washington Transportation Plan, Phase 2 - Implementation 2017-2040.

Washington State Department of Transportation. (2015). Washington Transportation Plan 2035.

Washington State Department of Transportation. (2019). Washington State Rail System Plan.

Zyngier, D., Lategan, J., \& Furstenberg, L. (2017). A Process Systems Approach for Detailed Rail Planning and Scheduling Applications. 


\section{About the Authors}

\section{Eric C. Peterson}

Eric C. Peterson is a transportation policy advisor. He is currently addressing infrastructure funding and finance, public transportation, and intercity and high-speed passenger rail issues.

In his career, he has played key roles in many major transportation improvement initiatives in the Washington, D.C. Metropolitan area. Peterson has also held significant leadership roles on Capitol Hill with national and regional transportation associations. Additionally, he was the first Deputy Administrator of the Research and Innovative Technology Administration in the U.S. Department of Transportation.

Outside of his transportation engagements, Eric Peterson is a former Deputy Under Secretary for Travel and Tourism at the U.S. Department of Commerce. He was also a former Executive Director of the U.S. Consumer Product Safety Commission. Peterson also served for many years on the Arlington County, Virginia Economic Development Commission where he was Chairman of its Tourism Committee.

As an active member of the Transportation Research Board Intercity and High-Speed Rail Committee (AR010) and the American Public Transportation Association's Intercity and High-Speed Passenger Rail Committee, Peterson earned his undergraduate degree in Political Science from Nebraska Wesleyan University. He went on to earn his Master's degree from the School of Public Communication at Boston University. Finally, he is a research associate with the Mineta Transportation Institute at San José State University, is associated with the George Washington University Institute for Corporate Responsibility, and is a member of the Board of Regents of the Eno Center for Transportation.

\section{Wenbin Wei}

Dr. Wenbin Wei is a Professor in the Department of Aviation and Technology at the College of Engineering at San José State University. He is also an Affiliated Professor in the Department of Industrial and System Engineering as well as Director of the Human Automation Integration Lab (HAIL) at San José State University. He has a Ph.D. from the University of California, Berkeley in Transportation Engineering and Management.

Before joining the faculty at San José State University, Dr. Wei was a research analyst in the Department of Operation Research and Decision Support at American Airlines. Dr. Wei's research interests include: transportation planning; traffic control and management; multimodal transportation systems; rail and high-speed rail (HSR) transportation; airport and airline management; unmanned aerial vehicle (UAV); logistics; and supply chain management. 
Dr. Wei has obtained more than $\$ 2$ million for research grants from agencies such as FAA, NASA, and the California Department of Transportation. Dr. Wei has published more than 40 research papers in peer-reviewed journals in his field.

\section{Lydon M. George}

Lydon George is an aspiring urban planner and researcher. His focus lies in public and active transportation systems, racial and social equity in planning, and cultural enrichment in planning. He is a current graduate student in the Master of Urban Planning program at San José State University. George earned his B.A. in Economics with a minor in Sociology from the University of California, Santa Cruz.

George is currently providing research assistance to the Mineta Transportation Institute through the SJSU Research Foundation and has worked as an intern in the Transportation Planning Department at the Santa Clara Valley Transportation Authority. Here, he supports staff with transit research, GIS analysis, community outreach, and fieldwork. 
Founder, Honorable

Norman Mineta*

Secretary (ret.),

US Department of Transportation

Chair,

Abbas Mohaddes

President \& COO

Econolite Group Inc.

Vice Chair,

Will Kempton

Retired Transportation Executive

Executive Director,

Karen Philbrick, $\mathrm{PhD}^{*}$

Mineta Transportation Institute

San José State University

Winsome Bowen

Vice President, Project Development

Strategy

WSP

David Castagnetti

Co-Founder

Mehlman Castagnetti Rosen \&

Thomas

Maria Cino

Vice President, America \& U.S.

Government Relations

Hewlett-Packard Enterprise

Grace Crunican**

Owner

Crunican LLC

Donna DeMartino

Managing Director

Los Angeles-San Diego-San Luis

Obispo Rail Corridor Agency
John Flaherty

Senior Fellow

Silicon Valley American Leadership

Forum

William Flynn *

President \& CEO

Amtrak

Rose Guilbault

Board Member

Peninsula Corridor Joint Power

Board

Ian Jefferies*

President \& CEO

Association of American Railroads

Diane Woodend Jones

Principal \& Chair of Board

Lea \& Elliott, Inc.

David S. Kim*

Secretary

California State Transportation

Agency (CALSTA)

Therese McMillan

Executive Director

Metropolitan Transportation

Commission (MTC)

Jeff Morales

Managing Principal

InfraStrategies, LLC

Stephen Morrissey

Vice President - Regulatory and

Policy

United Airlines
Dan Moshavi, $\mathrm{PhD}^{*}$

Dean

Lucas College and GraduateSchool

of Business, San José State

University

Toks Omishakin*

Director

California Department of

Transportation (Caltrans)

Takayoshi Oshima

Chairman \& CEO

Allied Telesis, Inc.

Greg Regan

President

Transportation Trades Department, AFL-CIO

Kimberly Slaughter

CEO

Systra USA

Paul Skoutelas*

President \& CEO

American Public Transportation

Association (APTA)

Beverley Swaim-Staley

President

Union Station Redevelopment

Corporation

Jim Tymon*

Executive Director

American Association of State

Highway and Transportation

Officials (AASHTO)

$*$ Ex-Officio

** = Past Chair, Board of Trustees

\section{Directors}

Karen Philbrick, PhD

Executive Director

Hilary Nixon, PhD

Deputy Executive Director

Asha Weinstein Agrawal, PhD

Education Director

National Transportation Finance Center Director

Brian Michael Jenkins National Transportation Security Center Director

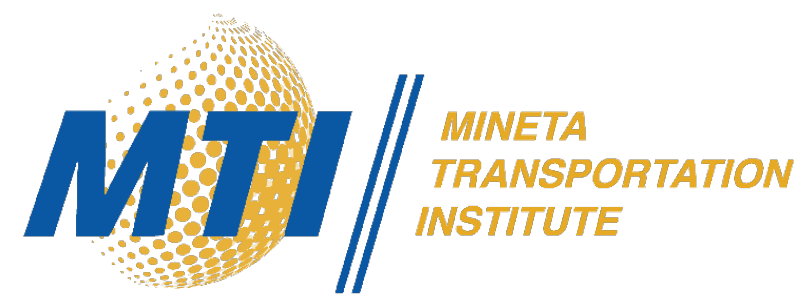

